\title{
CLIMATIC INFLUENCE ON THE PHYTOPLANKTON COMMUNITIES OF THE UPPER REACHES OF THE SOUTHERN BUG RIVER (UKRAINE)
}

\author{
Olena BILOUS *, Sophia BARINOVA ** \\ and Petro KLOCHENKO *** \\ * Hydrobiology Institute of NAS of Ukraine, Geroev Stalingrada Street 12, Kiev, Ukraine, UA-04210, \\ bilous_olena@ukr.net \\ ** Institute of Evolution, University of Haifa, Mount Carmel, Haifa, Israel, IL-31905, \\ barinova@reserch.haifa.ac.il \\ *** Hydrobiology Institute of NAS of Ukraine, Geroev Stalingrada Street 12, Kiev, Ukraine, UA-04210
}

DOI: $10.2478 /$ trser-2013-0020

KEYWORDS: algae, lotic systems, seasonal changes, bio-indication, monitoring.

\section{ABSTRACT}

A total of 98 taxa of algae were observed in phytoplankton, sampled monthly, from the Khmelnitsky monitoring station in the Southern Bug River, Ukraine, between April 2010 and March 2011. Chlorophyta species are the richest taxonomic group with 46 taxa, followed by Bacillariophyta, Euglenophyta, Cyanoprokaryota, Dinophyta, Chrysophyta, Streptophyta, and Xanthophyta. Seasonal dynamics of species distribution in taxonomic divisions shows that the role of Bacillariophyta in communities was high in January-March, which were replaced by greens in March-September. Euglenoids were developed in February-December and bluegreen algae in summer communities only. Strong positive correlations between temperature and species richness was observed. Abundance and biovolume of phytoplankton were maximal in summer, caused mostly by Dolichospermum flos-aquae (Lyngb.) Wacklin, Hoffmann and Komarek and Ceratium hirundinella (O. Müll.) Bergh. The river ecosystem has two periods of trophic levels - high at summer and low at winter. Bioindication characterizes the river as low alkaline and low mineralized with a moderate organic pollution level, revealed aspects of seasonal changes and revealed the main source of organic pollution as flowing from the catchment area during ice melting and rains. Organic pollution indices fluctuate within narrow limits suggesting relative stability of the river ecosystem that is shown also by Shannon indices. The calculated indices, comparative statistics, CCA, and bio-indication analysis exhibits a low pollution level in the Khmelnitsky monitoring station that can be used as a model of aquatic community dynamics under seasonal fluctuation in the southern boreal province climate, applicable for monitoring of the Southern Bug River.

ZUSAMMENFASSUNG: Der Einfluss des Klimas auf das Phytoplankton im Oberlauf des Bug-Flusses (Ukraine).

Am Oberlauf des Südlichen Bug, Ukraine, wurden an den monatlich beprobten Stellen im Monitoringgebiet Khmelnitsky zwischen April 2010 und März 2011 insgesamt 98 Taxa von phytoplanktonischen Algen festgestellt. Die Chlorophyten sind mit 46 systematischen Einheiten die reichste Gruppe, gefolgt von Arten der Bacillariophyta, Euglenophyta, Cyanoprokaryota, Dinophyta, Chrysophyta, Streptophyta und der Xanthophyta. Die jahreszeitliche Dynamik der Artenverteilung auf die taxonomischen Gruppen zeigen, dass während der Monate Januar bis März der Anteil der Bacillariophyta in den Gemeinschaften hoch war und die dann zwischen März und September von Grünalgen abgelöst wurden. Die 
Euglenophyta waren von Februar bis Dezember in den Proben vorhanden, während die BlauGrünalgen allein in den Sommergemeinschaften vorkamen. Es wurden enge positive Beziehungen zwischen Temperatur und Abundanz der Arten festgestellt. Abundanz und Biovolumen des Phytoplanktons zeigten während des Sommers Höchstwerte, die größtenteils bedingt waren durch das hohe Aufkommen von Dolichospermum flos-aquae (Lyngb.) Wacklin, Hoffmann and Komarek und Ceratium hirundinella (O. Müll.) Bergh. Das Ökosystem des Flusses hat zwei trophische Ebenen, eine hohe während des Sommers und eine niedrige während der Winterzeit. Anhand der Bioindikatoren wurde der Fluss im alkalinen Bereich, einer niedrigen Mineralisierung sowie einer moderaten organischen Belastung eingestuft und zeigte auch Aspekte der jahreszeitlichen Veränderungen. Außerdem konnte die Hauptquelle der organischen Belastung festgestellt werden, die sich während der Schneeschmelze und Regenwasser aus dem Einzugsgebiet sammelte. Die Indikatoren der organischen Belastung schwankten in engen Grenzen und wiesen dadurch auf eine relative Stabilität des Flussökosystems hin, die auch durch den Shannon-Index verdeutlicht wird. Die berechneten Indices, die vergleichenden statistischen Angaben, CCA sowie die Analyse der Bioindikatoren belegen eine niedrige Belastung im Beprobungsgebiet von Khmelnitsky, das als Beispiel für die Dynamik der aquatischen Gemeinschaften unter dem Einfluss jahreszeitlicher Schwankungen im Klimagebiet der südlichen borealen Provinz angesehen und für das Monitoring des Südlichen Bug verwendet werden kann.

REZUMAT: Influența climatică asupra comunităților fitoplanctonice din cursul superior al râului Bug de sud, Ucraina.

S-au observat un total de 98 taxoni de alge în fitoplanctonul studiat, pe baza unor eșantioane lunare, prelevate la stațiile de monitorizare Khmelnitsky în râul Bug, Ucraina, între aprilie 2010 și martie 2011. Chlorophyta reprezintă cel mai bogat grup taxonomic cu 46 taxoni, urmat de Bacillariophyta, Euglenophyta, Cyanoprokaryota, Dinophyta, Chrysophyta, Streptophyta şi Xanthophyta. Dinamica sezonieră a distribuției speciilor în diviziunile taxonomice arată că rolul Bacillariofitelor în comunități a fost ridicat în ianuarie-martie, fiind înlocuite cu alge verzi în martie-septembrie. Euglenophyta au fost observate în probele din februarie-decembrie și algele albastre-verzi doar în comunitățile de vară. Au fost observate strânse corelații pozitive între temperatură și abundența speciilor. Abundența și biovolumul fitoplanctonului au avut valori maxime în timpul verii, fiind cauzate în cea mai mare parte de Dolichospermum flos-aquae (Lyngb.) Wacklin, Hoffmann şi Komarek și Ceratium hirundinella (O. Müll.) Bergh. Ecosistemul râului are două perioade de nivele trofice, ridicate vara şi scăzute în timpul iernii. Cu ajutorul bioindicatorilor râul se prezintă la un nivel alcalin, mineralizare joasă şi de poluare organică moderată, relevându-se aspecte ale schimbărilor sezoniere. De asemenea, s-a putut depista principala sursă de poluare organică, care se colectează din bazinul hidrografic în timpul topirii gheții și a ploilor. Indicii de poluare organică fluctuează în limite înguste sugerând o stabilitate relativă a ecosistemului râului, care se arată, de asemenea, prin indicii Shannon. Indicii calculați, statisticile comparative, CCA și analizele de bio-indicatori scot în evidenţă un nivel scăzut de poluare, în staţia de monitorizare Khmelnitsky, care poate fi folosit ca un model pentru dinamica comunităților acvatice sub influența fluctuației sezoniere în climatul sudului provinciei boreale, aplicabil pentru monitorizarea Bugului de Sud. 


\section{INTRODUCTION}

The Southern Bug River is the largest in the West Ukrainian grassland region, with its catchment basin in the densely populated agricultural areas traversed by its numerous tributaries with sources of anthropogenic pollution.

The significant role of phytoplankton for aquatic ecosystems has already been studied (Abacumov, 1978, 1979) and data of its bioindication role in water bodies have also been revealed (Dokulil, 2003; Fedorov, 2004; Barinova et al., 2006, 2013). It is also necessary to uncover the particular role of phytoplankton in river ecosystems (Wehr and Descy, 1998). However, its spatio-temporal variability is relevant mostly to large rivers, which hasn't been sufficiently examined in the Ukraine. Seasonal observations are not enough; moreover, it isn't possible to conduct an appropriate ecological assessment and balance estimates to understand the processes that occur under climatic seasonality.

Southern Bug River phytoplankton, in spite of considerable and also modern works carried out (Klochenko and Mytkivska, 1994; Klochenko et al., 1993; Taraschuk, 2004), has not been properly explored in its upper reaches (Bilous et al., 2011). Therefore, it's necessary to draw attention to phytoplankton distribution and heterogeneity due to seasonal changes.

Our specific studies are more consistently related to bio-indication of the river ecological status, pollution impacts, and self-purification capacities, assessed according to the river management directives (***, 2000; Bajkiewicz-Grabowska, 2011) that emphasize the main importance of phytoplankton characteristics as the most informative component of the large river's ecosystem. Phytoplankton is obviously responsive to excessive input of inorganic nutrients, posing ecological problems for long stretches of the river affected by eutrophication, usually from land agricultural and industrial sources (Wehr and Descy, 1998).

We started our studies from the upper reaches (Bilous et al., 2011) and have presently extended to investigate the dynamics of phytoplankton communities in the referenced monitoring station at Khmelnitsky to determine the effects of seasonal variation and spatiotemporal variability in the river upper reaches.

\section{MATERIAL AND METHODS}

\section{Study Area}

The Southern Bug River is one of five large fluvial systems of the Western Steppe region. Out of all Ukrainian rivers, the Southern Bug is the largest river, whose basin belongs only to Ukrainian national territory (Fig. 1). Its catchment encompasses areas of the VolynPodolsk plateau and the Black Sea coastal basin (Sukhodolov et al., 2009). The catchment area of the Southern Bug River is approximately $63,700 \mathrm{~km}^{2}$, with a river length of $806 \mathrm{~km}$ (Vyshnevsky, 2000).

The basin territory stretches from the north-west to south-east and is defined by differences in temperature distribution. Thus, for the South Bug basin, wintertime is characterized by precipitation in rain and snow and is sometimes (cold winters) frozen over. The rise in air temperature is accompanied by cloudiness, breeze reduction, foggy days, and frequent thunderstorms in the spring. Clear days with significant temperature increases as well as a rise in precipitation and active thunderstorm activity are common in summer. In turn, autumn is characterized by an increase in cloudy days, continuous precipitation, and longcontinuous fogs (Lipinsky et al., 2003). 
We chose the Khmelnitsky site as referenced in our studies because it is located in the middle part of the Southern Bug River upper reaches and represents typical situations for the study region.

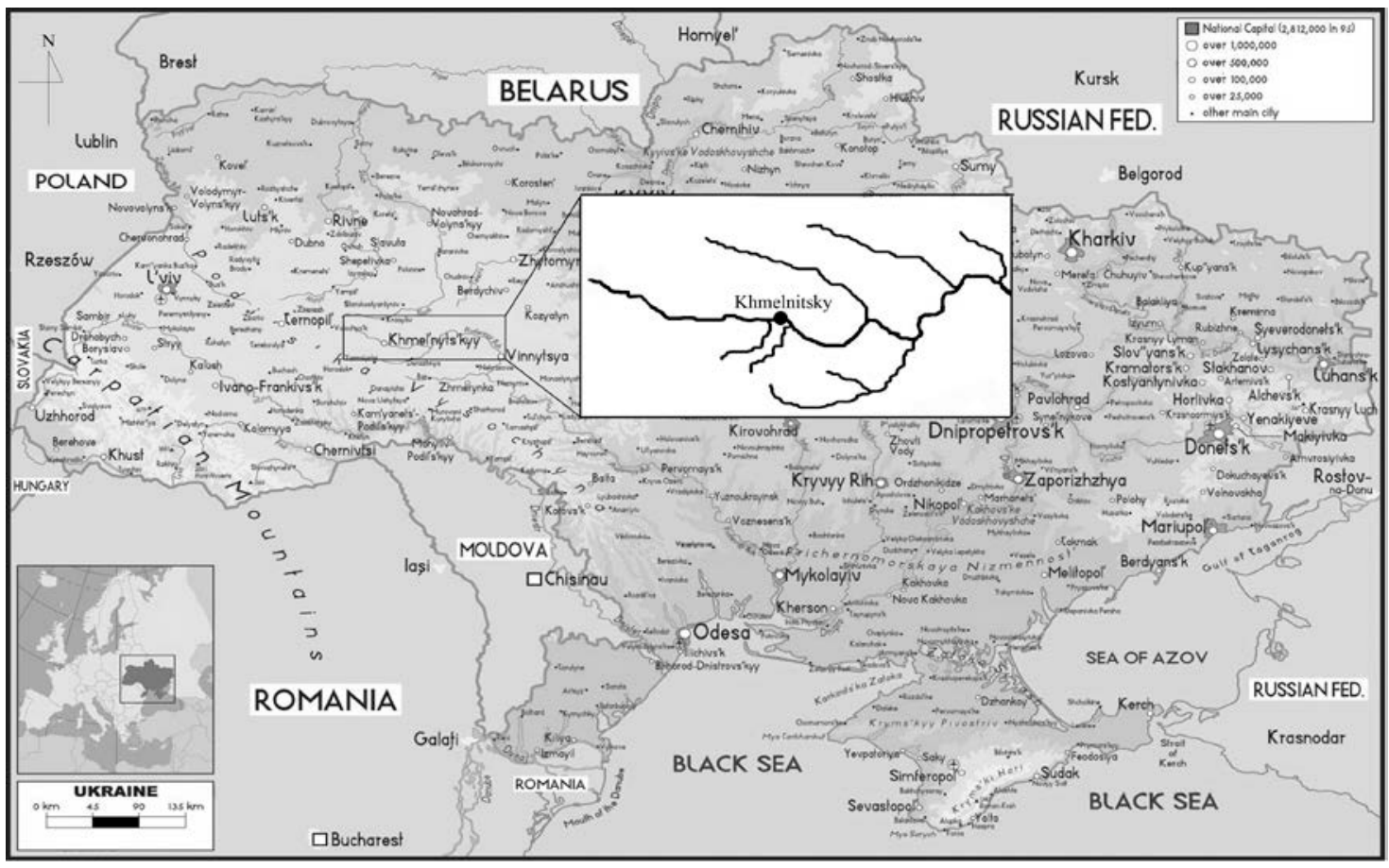

Figure 1: Map of the study site in the Southern Bug River.

\section{The experiment design}

The referenced monitoring station at Khmelnitsky, along the river, was sampled between April 2010 and March 2011, and we also measured hydrochemical variables for ammonia, nitrites, nitrates, and phosphates in summer.

Algological and hydrobiological samples of surface water were collected monthly with Ruttner's bathometer (Romanenko, 2006). The algological samples were investigated using Zeiss and PZO microscopes with living samples as well as fixed samples in a $4 \%$ final formaldehyde solution. For quantitative analyses, we used preliminary averaged samples and the counting of cells was carried out in a Nageotte Chamber $\left(0.2 \mathrm{~cm}^{3}\right)$. In turn, during the counting process, every colony and threadlike organism was considered to be an individual unit. In addition, for accurate definition of the Bacillariophyta species, we prepared permanent slides according to the method of Round (1953).

\section{Taxonomic identification}

For taxonomic identification of the potamoplankton taxa, a series of handbooks (Kondrat'eva, 1968; Asaul, 1975; Komárek and Fott, 1983; Starmach, 1983, 1985; Tsarenko, 1990; Krammer and Lange-Bertalot, 1991, 1997a, b, c; Lenzenweger, 1996, 1997, 1999; Krammer, 2000, 2002, 2003; Lange-Bertalot, 2001; Palamar-Mordvinceva, 2003, 2005; Komárek and Anagnostidis, 1998, 2005; Popovský and Pfiester, 2008; Kovalenko, 2009; Levkov, 2009) and selected papers were used (Tsarenko et al., 2005). 


\section{Bio-indication}

Our ecological analysis has revealed a grouping of freshwater algae indicators to $\mathrm{pH}$, salinity, and saprobity as well as for other habitat conditions (Barinova et al., 2006). Each group was separately assessed with respect to its bioindication significance. Those species that respond to environmental variables can be used as bioindicators reflecting the responses of aquatic ecosystems to eutrophication, $\mathrm{pH}$ levels (acidifications), salinity, and organic pollution.

\section{Density-Diversity indices and statistics}

Saprobity indices were calculated on the basis of identified species abundance and individual indices:

$$
\mathrm{S}=\sum_{i=1}^{n}\left(\mathbf{s}_{i} \cdot \mathrm{a}_{i}\right) / \sum_{i=1}^{n}\left(\mathrm{a}_{i}\right)
$$

where: S - Index saprobity of algal community; $s_{i}$ - species-specific saprobity index; $\mathrm{a}_{i}$ - species abundance.

Shannon's diversity index (Odum, 1969) was calculated as:

$$
\bar{H}=-\sum_{i=1}^{s} \frac{n_{i}}{N} \log _{2} \frac{n_{i}}{N}(2)
$$

where: $N=$ common organisms abundance, $\mathrm{l} ; s=$ species number; $n_{i}=$ species number of every species; = Shannon diversity index, bit.

Statistical methods were used in comparative floristic approaches (Novakovsky, 2004) for calculating similarity of algal communities monthly.

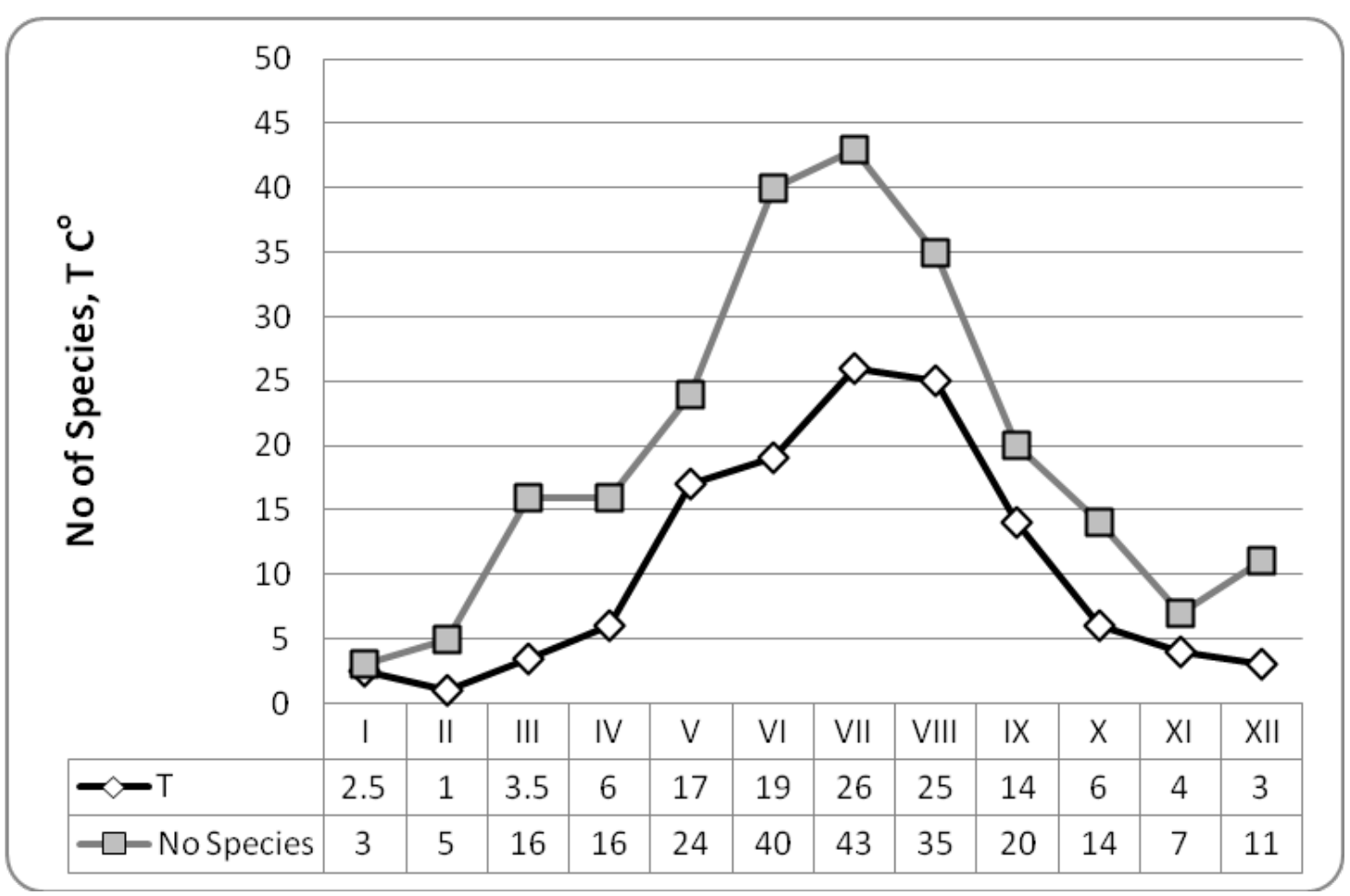

Figure 2: Water temperature and phytoplankton species richness variation during the year. 
As a whole, Chlorophyta species are the richest taxonomic group with a total of 46 taxa, followed by Bacillariophyta (20 taxa), Euglenophyta (13 taxa), Cyanoprokaryota (eight taxa), Dinophyta and Chrysophyta (four taxa each), Streptophyta (two taxa), and Xanthophyta (one taxa). Seasonal dynamics of species distribution in taxonomic divisions during the study period show the complexity of communities in potamoplankton on the Southern Bug River (Fig. 2).

As it can be seen, the role of Bacillariophyta in communities was high in JanuaryMarch, and diatoms were replaced by green algae during March-September. Blue-green algae developed in summer communities only. It is interesting that the third richest group was euglenoids, which enrich planktonic communities in February-December.

Chlorophyta species were the majority in planktonic communities of the Khmelnitsky site in the Southern Bug River and increased during the vegetation season from March to September with fluctuation till December (Fig. 3). The domination of the Chlorophyta in plankton is quite common for Ukrainian rivers (Vasenko et al., 2002; Vladymyrova, 1976) as well as in the other large rivers of the Black Sea basin (Azari et al., 2011; Marvan et al., 2004). The presence of this division has some variations throughout the study period, as we can see in figure 3, in winter and early spring communities were enriched by Bacillariophyta. The presence of other divisions during the year wasn't so impressive based on the number of species.

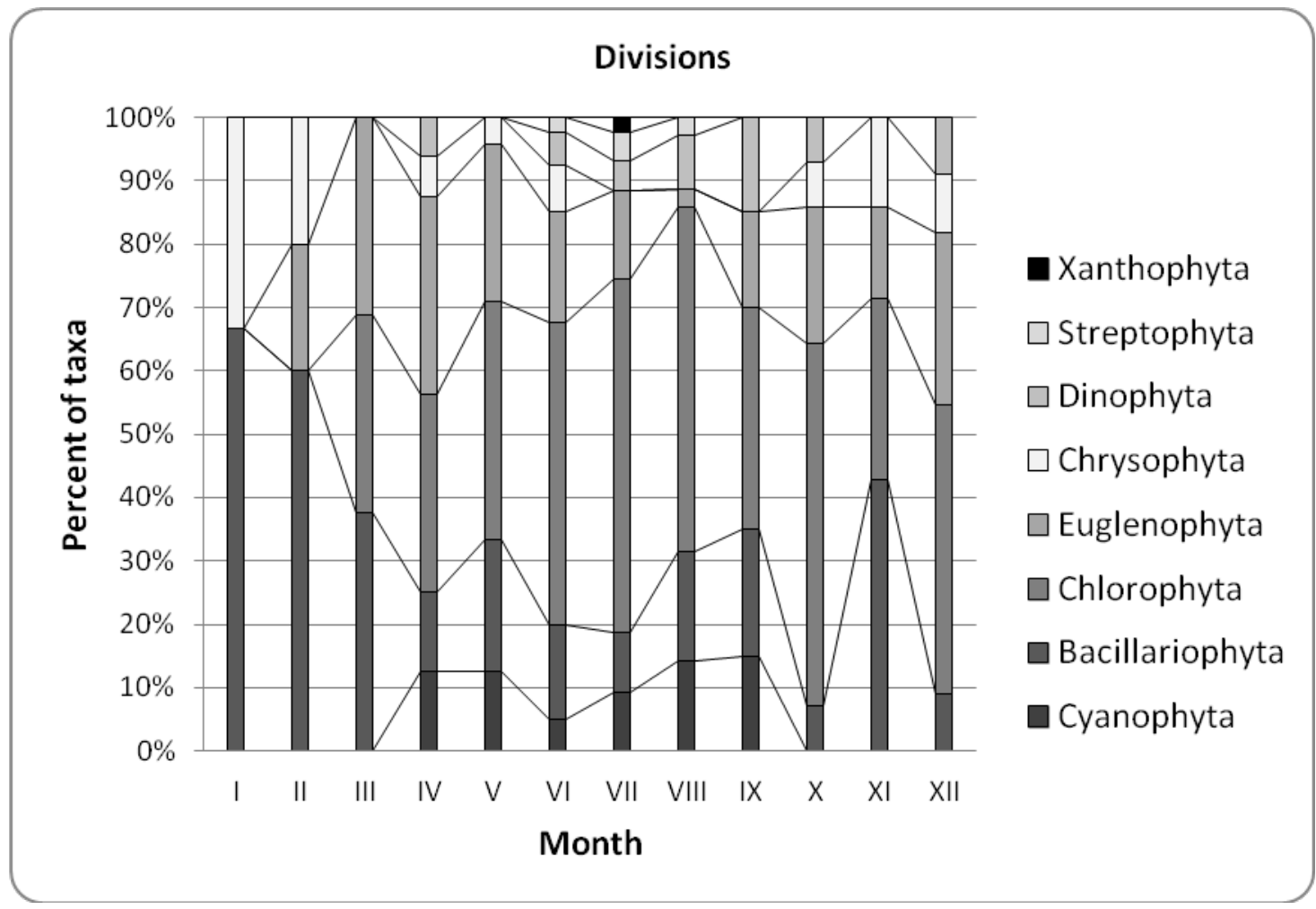

Figure 3: Seasonal dynamics of algal diversity in planktonic communities of the Khmelnitsky site in the Southern Bug River. 
Species richness variation represents one peak during the year as seen in figure 2 . Therefore, it is difficult to delimit seasonal complexes of phytoplankton. We used a statistical approach to define relationships between planktonic communities' species richness of the Khmelnitsky site (Fig. 4) and revealed seasonal groups of phytoplankton. A comparison of species content overlapping between monthly measured algal diversity shows high similarity between January-February, April-May, and July-August communities.

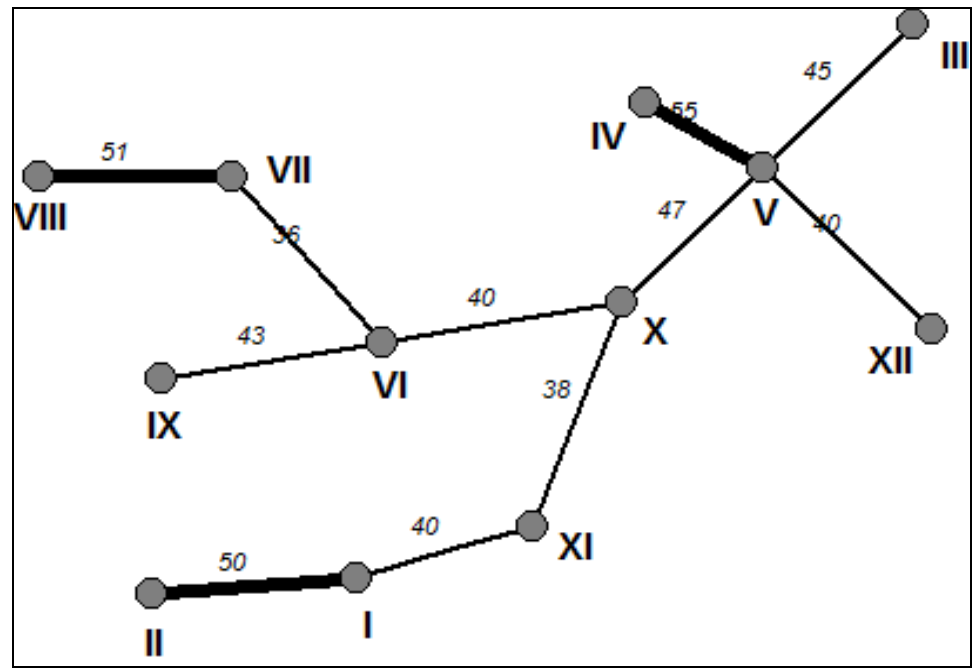

Figure 4: Dendrite of species richness overlapping planktonic communities

in the Khmelnitsky site of the Southern Bug River based on Serensen-Chekanovsky indices; circles numbered with respect to the sampling month, bold lines mark relationships between communities.

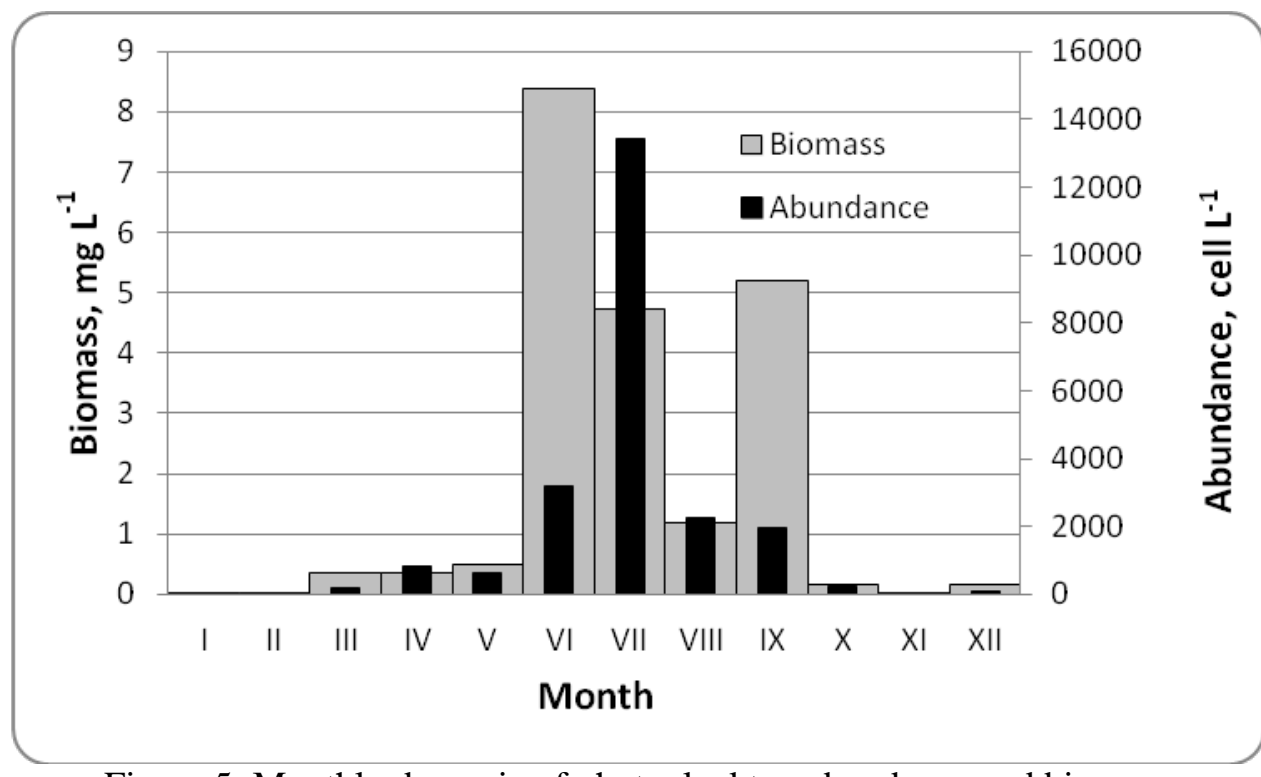

Figure 5: Monthly dynamic of phytoplankton abundance and biomass in the Khmelnitsky monitoring station of the southern Bug River. 
Algal species abundance and their occurrence by month are represented in Appendix 1. Abundance and biovolume of phytoplankton were maximal in summer with $13.416 \mathrm{mln}$ cells $\mathrm{l}^{-1}$ in July and $8.374 \mathrm{mg} \mathrm{l}^{-1}$ in June. It's seen that abundance maximum is caused by Dolichospermum flos-aquae (Lyngb.) Wacklin, Hoffmann and Komarek with 3.780 mln cells $\mathrm{l}^{-1}$, and biovolume maximum by Ceratium hirundinella (O. Müll.) Bergh. with $2.355 \mathrm{mg} \mathrm{l}^{-1}$. In summer we observed the Cyanoprokaryota complex with Dolichospermum flos-aquae and Aphanizomenon flos-aquae domination. The Dinophyta complex was observed in autumn with the domination of Ceratium hirundinella. The Chrysophyta-Bacillariophyta complex was observed in winter, with Aulacoseira granulata and Pseudokephyrion cylindricum domination. Bacillariophyta complex was observed in the spring, with the domination of Aulacoseira granulata and Melosira varians.

The phytoplankton abundance and biomass altered with respect to the change in water temperature and can be observed in three seasons during the year (Fig. 5). Remarkably, in southern rivers (which have higher water temperatures and different seasonal aspects), there are only two seasons (Barinova and Tavassi, 2009). The plankton cells' abundance changes are dramatically sharp during the year. Abundance is at a minimum in winter as well as during flooding due to water dilution from melted snow. Plankton abundance and biomass increase in spring with fluctuations related to water level changes. When the level of abundance and biomass is low, water from the plankton rich tributaries, enters the river channel and potamoplankton become more abundant. After summer, the maximum plankton abundance begins to decline due to many organisms transitions at bottom resting forms existence. The number of plankton, leading active lives during the year was not numerous in autumn due to the deterioration of food, and, as a result their rate of reproduction, was decreased (Konstantinov, 1986) as seen in the studied site. Pertaining to the division of distribution, we observed significant abundance and biomass of phytoplankton in the monitoring station for every month of a year. In summer, the most demonstrative division, according to abundance was Cyanoprokaryota; at the same time, greater biomass was observed for the Dinophyta division. This phenomenon easily explains the proper time for vegetation of these groups in this period. Along with lower temperatures, the food quantity decreased causing a decrease in phytoplankton abundance. In autumn Bacillariophyta was noted for its abundance and Dinophyta for its biomass. Distinguished divisions for abundance was Chlorophyta and for biomass - Bacillariophyta in winter time. The cyanobacteria abundance has its major role in the spring, whereas diatoms also formed significant biomass in the spring. We observed strong correlation between abundance and water temperature over the studied year, though some authors (Atici and Obali, 2010) indicated a delay in abundance in comparison with temperature trend. Other chemical variables that we measured in this important river ecosystem study period reflect low-alkaline middle-polluted water, and only ammonia in summer was slightly increased.

To reveal the community complexity fluctuation over climatic seasons, we calculated the Shannon diversity indices on the basis of Appendix 1. As can be seen in figure 6, Shannon index values fluctuated over the year, but as a whole, high values during the summer algal activity can be seen from May till September. Calculated cell biovolume for the planktonic algae community for each month (based on Appendix 1, as a result of dividing the measured monthly biomass of plankton by its cells' abundance) has similar fluctuation with Shannon index all year-round, and it was opposite only in September (Fig. 6). 


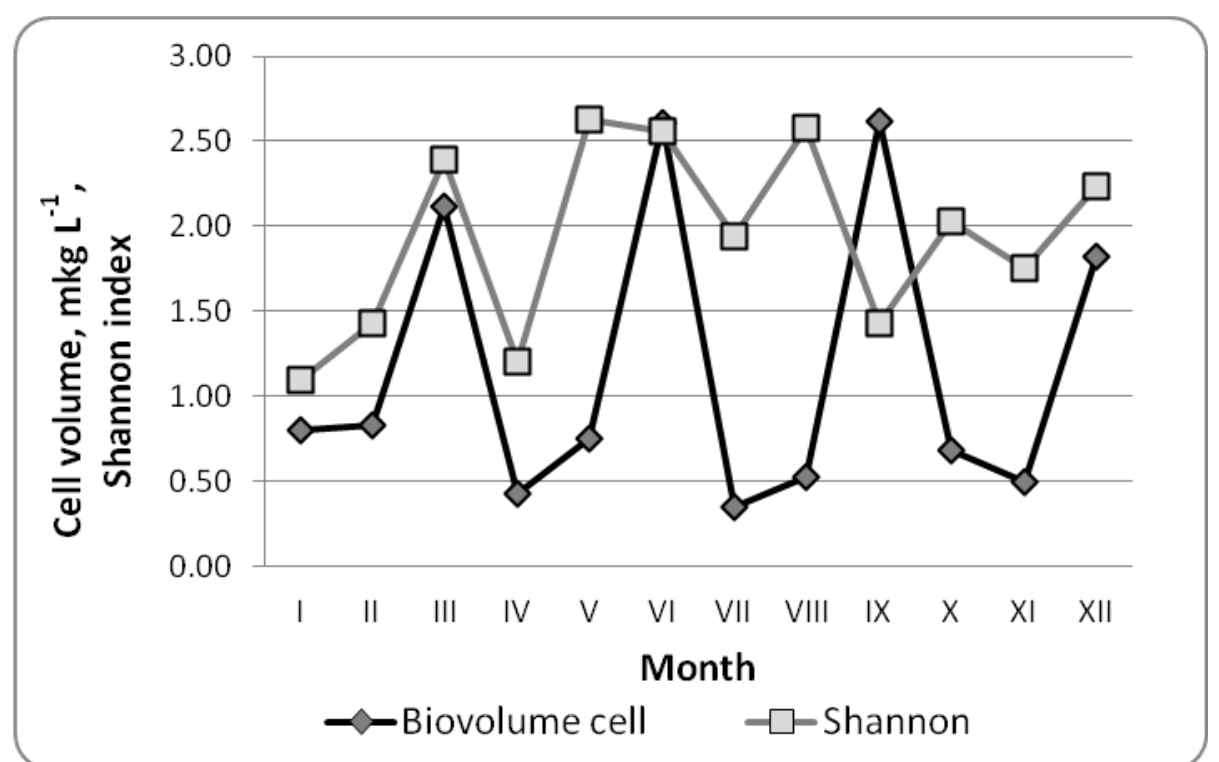

Figure 6: Dynamic of Shannon index and cell biovolume (mkg l${ }^{-1}$ ) calculated for the planktonic communities of the Khmelnitsky site in the southern Bug River.

Figure 6 reveals community complexity correlated with cell biovolume - calculated on the basis of biomass and abundance data (Appendix 1). Periods of decreased cell biovolume reflected small cell species development in communities and therefore community structure change (Barinova et al., 2006; Barinova, 2011; Barinova and Nevo, 2012). In other words, a healthy community state is when species richness is high, algal cells having high volume, and community structure is diverse and complex, e.g., in March, July, and December.

The bioindication analysis of algal species' representation over ecological categories shows (Appendix 2) that the planktonic communities (Appendix 1) included planktonic, plankto-benthic, and some benthic inhabitants. In February and March the plankton were enriched by benthic cells, whereas the community was assembled on $90 \%$ of authentic planktonic inhabitants in the ice free period. The temperature indicators changed from coolwater to eurythermic and temperate species during the ice free period from April to November. Indicators of water mass mobility reveal low streaming species over the seasons and indicate the river water as moderately enriched by oxygen. Dynamics of acidity indicator species show low alkaline water with two periods of different species domination, March-July with Melosira varians and August-September with Cymbella lanceolata. Two groups, mesohalobe and oligohalobious-halophilous species, reveal some peaks of salinity influence over the year. It can be observed in April with Euglena granulata and in September-December with Aphanizomenon flos-aquae and Oscillatoria tenuis.

According to organic pollution, the Class III indicators prevailed during the year. Some groups of algae that are Class $\mathrm{V}$ indicators of water quality are also indicators in communities from March till November, dominated by Melosira varians and Fragilaria crotonensis. Moreover, the number of saprobic species also increased from April-May and September-October. Species ecology data from Appendix 2 show that photosynthetic activity of algal communities described in Van Dam et al. (1994) were very high with mostly autotrophic species over the year, whereas in September, heterotrophic species dominated. 
Indicators of a trophic state mostly revealed eutraphentic species during the year. At the same time, we observe an invasion of high trophic state indicators in March, June, and December communities. As a whole, planktonic communities in the referenced monitoring station reflect a medium trophic state of the ecosystem in the studied area of the Southern Bug River.

Bioindication, as a method of environmental variables' biotic assessments, reveals phytoplankton communities' response to environmental changes (Dokulil, 2003). Studied communities on the Southern Bug River site included mostly planktonic and plankto-benthic species which reveals some aspects of river-like reach of the studied part of the river. At the same time we found some benthic forms over a year that indicate water turbulence. As a result of weather conditions and warm temperatures, we can see eurythermic and temperate species increasing from April to November and cool species decreasing at the same time. Moreover, their absence after June, when the temperature is more than $20-25^{\circ} \mathrm{C}$, indicated homothermous water in the river.

The water in the monitoring station is moderately oxygenated throughout the year, but from November till January, when mobility of the water mass is less, we recorded an increase in standing water species indicators in communities.

The rise in the salinity level due to melted water, washed away some dissolved solids from the soil's surface. We observed two periods of decreased $\mathrm{pH}$ - from March to July and from July till October, which correlate with rainy periods in the Ukraine. Bioindication results also show the impact of salinity during the year where we found two periods of increased water salinity - in April and September-December. It can be correlated also with melting and rainy periods, as we found in water $\mathrm{pH}$ fluctuation.

The weather conditions (the snow melting in April) are accompanied with organic pollution, which is confirmed by increases in the alpha-mesosaprobic algal indicators group and can be observed in March-April. The same increase in indicators of pollution can be seen during August-September when the weather is rainy. In the ice free period (March-November) organic pollution is higher than during freezing of the river when the water is protected by snow (as in February). Species indicators, such as saprophilous species, under the Watenabe's organic pollution assessment system, increase abundance in April-May and SeptemberOctober which indicates an increase in water pollution when the ice cover isn't protected from pollutants and summer species don't consume. Therefore bioindications are revealed flowing from the catchment area during ice melting and rains are the main source of organic pollution.

Due to high abundance and biomass of algae in summer time, especially in July and August, photosynthetic activity of algal communities was higher during the rest of the year. The heterotrophic species indicators, which dominated in September when the abundance and biomass of phytoplankton were lower, correlated with light amount and decrease of water temperature. The increase of eutraphentic species in March, June, and December shows a lower photosynthetic activity level, along with temperature and insolation reduction, which resulted in a decrease in the ecosystem's trophic state. There were a lot of available organics which fluctuated with eutraphentic species and were quite rich in species diversity with abundance and biomass.

We calculated the saprobity indices $\mathrm{S}$ on the basis of our database (Barinova et al., 2006) and cell abundance in Appendix 1. The index value fluctuated between 1.73 and 2.32, which indicated Class III water quality during the year. It is remarkable that the highest value of index S was in June and September, but the trend line (Fig. 7) showed highest index values in the summer season. 


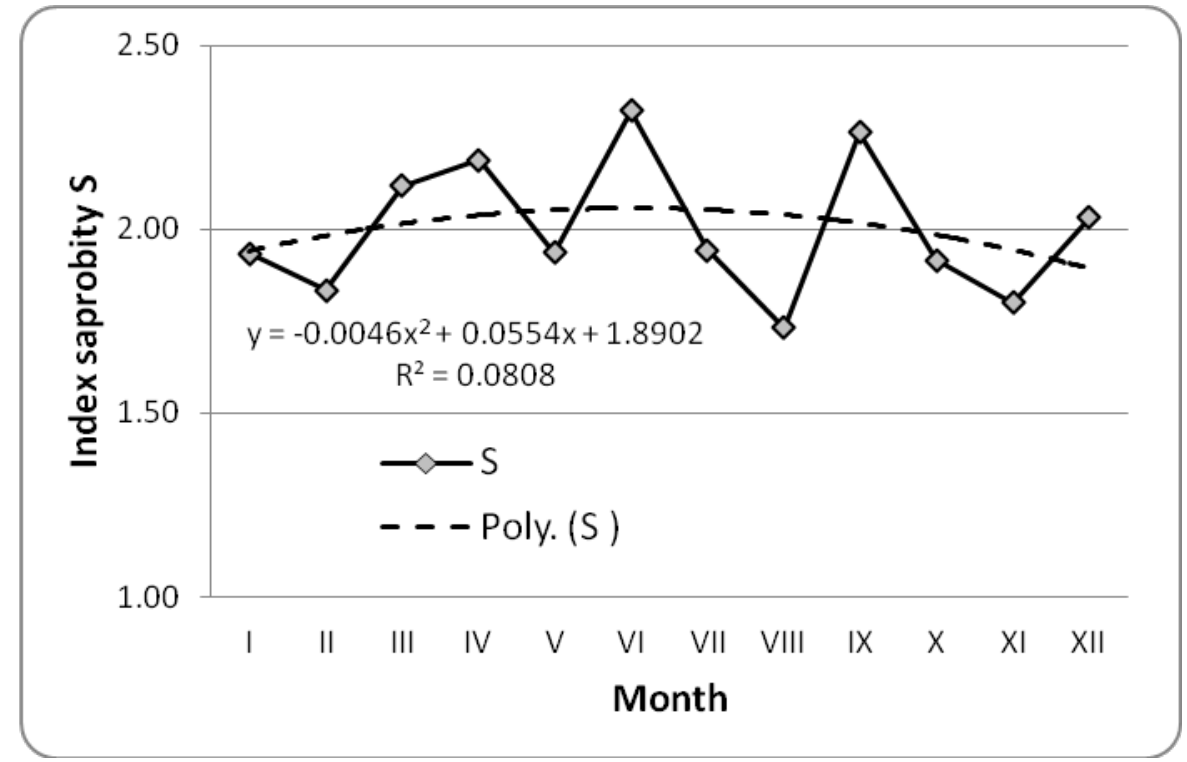

Figure 7: Monthly dynamic of the Saprobity index S during studied period of 2010-2011.

\section{CONCLUSIONS}

The planktonic communities of the Khmelnitsky referenced site in the Southern Bug River upper reaches helped us to conclude that river ecosystems have two periods of trophic levels - high in the summer and low in winter. This coincides with abundance and biomass fluctuation and relates mostly with the major environmental variable for the studied river - the water temperature. Bioindication methods, which were implemented for the first time for the southern Bug River helped us characterize the river water in investigating the upper reaches as being low alkaline and low minerals with a moderate organic pollution level. Organic pollution indices fluctuate within the narrow limits, suggesting a relative stability of the river ecosystem that might have coped with organic pollution by adjusting the abundance and biomass of the algal phytoplankton to the seasonal climatic condition.

But the highest value of phytoplankton in June is common in the Black Sea Basin (Solak, 2012). We observed a strong seasonal component in phytoplankton diversity, which is confirmed by the Shannon diversity index. This fact is also shown in other investigations (Şahin et al., 2010; Baykal et al., 2011). Moreover, the abiotic analysis of our investigations confirmed measured biotic parameters as well as the significant role of green algae in planktonic community activity.

As a whole, our analysis shows the important role of temperature in the efficient selfpurification ability of the studied river ecosystem. Therefore, climatic seasonality plays a major role in phytoplankton activity in which has the highest activity in summer. In addition, this information can be used in making decisions for the use of water resources for conservation and in the effective utilization of water bodies, such as large rivers in the Ukraine and closely related climatic regions.

\section{ACKNOWLEDGEMENTS}

The authors acknowledge the financial support of the Ministry of Absorption of Israel. 


\section{REFERENCES}

1. Abakumov V. A., 1978 - About observations and comparison assessment of ecology systems. Problems of ecology monitoring and ecosystem modelling, 1, Gidrometeoizdat, Leningrad, 6472. (in Russian)

2. Abakumov V. A., 1979 - Main direction of water biocoenosis changes in contamination of environment conditions. Problems of ecology monitoring and ecosystem modelling, T. 2., Gidrometeoizdat, Leningrad, 37-47. (in Russian)

3. Asaul Z. I., 1975 - Identification book of Euglenophyta in Ukraine, Kiev, Ukraine, Naukova Dumka, 408. (in Ukrainian)

4. Atici T. and Obali O., 2010 - The diatoms of Asartepe Dam Lake (Ankara), with environmental and some physicochemical properties, Turkish Journal of Botany, 34, 541-548.

5. Azari A. M., Mohebbi F. and Asem A., 2011 - Seasonal changes in phytoplankton community structure in relation to physico-chemical factors in Bukan Dam reservoir (north-west Iran), Turkish Journal of Botany, 35, 77-84.

6. Bajkiewicz-Grabowska E., 2011 - Assessment of the ecological state of lakes as proposed by the Polish Limnological Society, Limnological Review, 10, 3-4, 105-180.

7. Barinova S., 2011 - Algal diversity dynamics, ecological assessment, and monitoring in the river ecosystems of the eastern Mediterranean, New York, USA: Nova Science Publishers, 363.

8. Barinova S. S., Medvedeva L. A. and Anissimova O. V., 2006 - Diversity of algal indicators in environmental assessment, Pilies Studio, Tel Aviv, Israel, 498. (in Russian)

9. Barinova S. and Tavassi M., 2009 - Study of seasonal influences on algal biodiversity in the River Yarqon (central Israel) by bio-indication and canonical correspondence analysis (CCA), Turkish Journal of Botany, 33, 353-372.

10. Barinova S. S. and Nevo E., 2012 - Algal diversity of the Akko Park in the Bahai Gardens (Haifa, Israel), Transylvanian Review of Systematical and Ecological Research, CurteanBănăduc et al. (eds), 14, 55-80.

11. Barinova S., Keshri J., Ghosh S. and Sikdar J., 2013 - The influence of the monsoon climate on phytoplankton in the Shibpukur pool of Shiva temple in Burdwan, West Bengal, India, Limnological Review, 12, 2, 47-100.

12. Baykal T., Açikgöz İ., Abel U. and Yildiz K., 2011 - Seasonal variations in phytoplankton composition and biomass in a small lowland river-lake system (Melen River, Turkey), Turkish Journal of Botany, 35, 485-501.

13. Bilous O., Barinova S. and Klochenko P., 2011 - Phytoplankton diversity and ecological assessment of the upper part of the Southern Bug River basin, Ukraine, Abstracts of (3rd) Aquatic Biodiversity International Conference, Sibiu/Transylvania/Romania/European Union, 66.

14. Dokulil M. T., 2003 - Algae as ecological bioindicators, in Market B. A., Breure A. M., Zechmeistter H. G. (eds), Bioindicators and Biomonitors, Oxford, U. K, 285-327.

15. Fedorov V. D., 2004 - Changes in the biological systems, Moscow, Russia: Sport and Culture, 368. (in Russian)

16. Hustedt F., 1957 - Die Diatomeenfl ora des Flußsystems der Weser im Gebiet der Hansestadt Bremen, Abhandlungen Naturwissenschaft Verein Bremen, 34, 181-440.

17. Klochenko P. D., Mytkivska T. I. and Sakevich A. I., 1993 - Phytoplankton of the Nikolaev region small rivers (Ukraine), Algologia, 3, 57-63. (in Russian)

18. Klochenko P. D. and Mytkivska T. I., 1994 - Phytoplankton of the Southern Bug River at the territory between Pervomajs'k and Mykolaev (Ukraine), Ukrainian Botanic Journal, 51, 116-124. (in Ukrainian)

19. Komárek J. and Fott B., 1983 - Das Phytoplankton des Süsswassers. Systematik und Biologie, in Huber-Pestalozzi G. (ed.), Stuttgart, Germany, E. Schweizerbart'sche Verlagsbuchhandlung, 1000. (in German) 
20. Komárek J. and Anagnostidis K., 1998 - Cyanoprokaryota. Teil 1: Chroococcales, in Ettl H., Gärtner G., Heynig H., Mollenhauer D. (eds), Süsswasserflora von Mitteleuropa 19/1, Stuttgart, Lübeck, Ulm, Jena, Gustav Fisher Verlag, 548. (in German)

21. Komárek J. and Anagnostidis K., 2005 - Cyanoprokaryota. Teil 2.: Oscillatoriales, in Büdel B., Gärtner G., Krienitz L. and Schagerl M. (eds), Süsswasserflora von Mitteleuropa 19/2, München, Germany, Elsevier, 759. (in German)

22. Kondrat'eva N. V., 1968 - Cyanophyta. Class Hormogoniophyceae, 1, 2, in Topachevskyy O. V. (ed.), Identification book of freshwater algae in Ukraine, Kiev, Ukraine, Naukova Dumka, 524. (in Ukrainian)

23. Konstantinov A. S., 1986 - Hydrobiology. Moskow, Vysshaya Shkola, 472. (in Russian)

24. Kovalenko O. V., 2009 - Cyanophyta. Order: Chroococcales, 1, 2, Output 1, in Tsarenko P. M. (ed.), Flora of algae of Ukraine, Kiev, Ukraine, Aristey, 397. (in Ukrainian)

25. Krammer K., 2000 - The genus Pinnularia, 1, in Lange-Bertalot H. (ed.), Diatoms of Europe, Ruggell: A. R. G. Gantner Verlag K. G., 703.

26. Krammer K., 2002 - Cymbella V.3., in Lange-Bertalot H. (ed.) Diatoms of Europe, Ruggell: A. R. G. Gantner Verlag K. G., 584.

27. Krammer K., 2003 - Cymbopleura, Delicata, Navicymbula, Gomphocymbellopsis, Afrocymbella, V.4., in Lange-Bertalot H. (ed.), Diatoms of Europe, Ruggell: A. R. G. Gantner Verlag K. G., 530.

28. Krammer K. and Lange-Bertalot H., 1991 - Bacillariophyceae. Centrales, Fragilariaceae, Eunotiaceae, 3, in Pascher A. and Ettl H. (eds), Süßwasserflora von Mitteleuropa, Bd. 2/3. Stuttgart, Jena, Fischer G., 576. (in German)

29. Krammer K. and Lange-Bertalot H., 1997a - Bacillariophyceae. Naviculaceae, 1, in Pascher A. and Ettl H. (eds), Süßwasserflora von Mitteleuropa, Bd. 2/1, Stuttgart, Jena, Fischer G. Verlag, 876. (in German)

30. Krammer K. and Lange-Bertalot H., 1997b - Bacillariaceae, Epithemiaceae, Surirellaceae, 2, in Pascher A. and Ettl H. (eds), Süßwasserflora von Mitteleuropa, Jena, Stuttgart, Lübeck, Ulm, Fischer G. Verlag, 611. (in German)

31. Krammer K. and Lange-Bertalot H., 1997c - Bacillariaceae, Epithemiaceae, Surirellaceae, Teil 2, in Pascher A. and Ettl H. (eds), Süsswasserflora von Mitteleuropa, Jena, Stuttgard, Lübeck, Ulm: Fischer G. Verlag, 1988. (in German)

32. Lange-Bertalot H., 2001 - Navicula sensu stricto, V. 2., in Lange-Bertalot H. (ed.), Diatoms of Europe, Ruggell: Gantner A. R. G. Verlag K. G., 526.

33. Lenzenweger R., 1996 - Desmidiaceenflora von Österreich, Bibliotheca Phycologica, 101, Berlin-Stuttgart, Cramer J., 162. (in German)

34. Lenzenweger R., 1997 - Desmidiaceenflora von Österreich, Bibliotheca Phycologica, 102, Berlin-Stuttgart, Cramer J., 216. (in German)

35. Lenzenweger R., 1999 - Desmidiaceenflora von Österreich, Bibliotheca Phycologica, 104, Berlin-Stuttgart, Cramer J., 218. (in German)

36. Levkov Z., 2009 - Amphora sensu lato in Lange-Bertalot H. (ed.), Diatoms of Europe, Ruggell: A. R. G. Gantner Verlag K.G., 916.

37. Lipinsky V. M., Dyachuck V. A. and Babichenko V. M. (eds), 2003 - Climate of the Ukraine, Kiev, Ukraine, Raevskogo Press, 345. (in Russian)

38. Marvan P., Heteša J., Hindák F. and Hindáková A., 2004 - Phytoplankton of the Morava River in Czech Republic and Slovakia: past and present, Oceanological and Hydrobiological Studies, XXXIII, 4, 41-60.

39. Novakovsky A. B. 2004 - Vozmozhnosti i princypy raboty programnogo modulya "GRAPHS”, Avtomatizaciya nauchnych issledovaniy, Abilities and base principles of program module "GRAPHS”, Komi Nauchnyy Center, Ural’skoe Otdelenie Russkoy Academii Nauk, Syktyvkar 27, 1-28. (in Russian) 
40. Palamar-Mordvintseva G. M., 2003 - Desmidievi (Desmidiales), Gonatozigovi, Penievi, Closterievi, in Tsarenko P. M. (ed.), Algal Flora of continental waterbodies of Ukraine, Kiev, Ukraine, Naukova Dumka, 354. (in Ukrainian)

41. Palamar'-Mordvintseva G. M., 2005 - Desmidievi (Desmidiales), in Tsarenko P. M. (ed.), Algal Flora of continental water bodies of Ukraine, Kiev, Ukraine, Naukova Dumka, 573. (in Ukrainian)

42. Popovský J. and Pfiester L. A., 2008 - Dinophyceae (Dinoflagellida), in Ettl H., Gerloff J., Heynig H. and Mollenhauer D. (eds), Susswasserflora von Mitteleuropa, 6, Jena, Stuttgart, Germany, Fischer G. Verlag, 272. (in German)

43. Romanenko V. D. (ed.), 2006 - Hidroecology investigation methods of headwaters, Kiev, Ukraine, Logos, 408. (in Ukrainian)

44. Round F. E., 1953 - An investigation of two bentic algal communities in Malharm Tarn, Yorkshire, Journal of Ecology, 41, 97-174.

45. Solak C. N., Barinova S., Acs E. and Dayioglu H., 2012 - Diversity and ecology of diatoms from Felent creek (Sakarya River basin), Turkey, Turkish Journal of Botany, 36, 191-203.

46. Starmach K., 1983 - Euglenophyta, 3, in Starmach K. and Siemińska J. (eds), Flora Słodkowodna Polski, Warszawa, Kraków, Poland, Państowe Wydawnictwo Naukowe, 593. (in Polish)

47. Starmach K. B., 1985 - Chrysophyceae und Haptophyceae, in Ettl H. and Gerloff J., Heynig H., Mollenhauer D. (eds), Süsswasserflora von Mitteleuropa, Stuttgart, New York, Gustav Fischer Verlag, 514. (in German)

48. Sládeček V., 1973 - System of water quality from the biological point of view. Ergebnisse Limnologie 7, 1-128.

49. Sládeček V., 1986 - Diatoms as indicators of organic pollution, Acta Hydrochemica und Hydrobiologica, 14, 555-566.

50. Sukhodolov A. N., Arnaut N. A., Kudersky L. A., Loboda N. S., Bekh V. V., Skakalsky B. G., Katolikov V. M. and Usatii M. A., 2009 - Western Steppic Rivers, in Tockner K., Robinson C. T., Uehlinger U. (eds), Rivers of Europe, Amsterdam, Boston, Heidelberg, London, New York, Oxford, Paris, San Diego, San Francisco, Singapore, Sydney, Tokyo, Academic Press, Elsevier, 515-540.

51. Şahin B., Akar B. and Bachceci I., 2010 - Species composition and diversity of epipelic algae in Balık Lake (Savşat-Artvin, Turkey), Turkish Journal of Botany, 34, 441-448.

52. Taraschuk O. S., 2004 - Diatoms of lower part of Southern Bug (Ukraine), Algologia, 14, 3, 309-324. (in Russian)

53. Tsarenko P. M., 1990 - Short identification book of Chlorococcales in Ukraine, Kiev, Ukraine, Naukova Dumka, 208. (in Russian)

54. Tsarenko P. M., Hegewald E. and Braband A., 2005 - Scenedesmus-like algae of Ukraine, Algological Studies, 118, 1-45.

55. Van Dam H., Mertens A. and Sinkeldam J., 1994 - A coded checklist and ecological indicator values of freshwater diatoms from The Netherlands, Netherlands Journal of Aquatic Ecology, 28, 117-133.

56. Vasenko A. G., Glyschenko L. F., Sereda T. N. and Manturova O. V., 2002 - Phytoplankton, in Vasenko A. G. and Afanas'ev S. A. (eds), Ekological state of transboundary plots of Dnipro River basin on Ukraine territory, Kiev, Ukraine, Akademperiodika, 103-120. (in Russian)

57. Vladymyrova K. S. (ed.), 1967 - Dnipro hydrobiological regime in controlled flow, Kiev, Ukraine, Naukova Dumka, 387. (in Russian)

58. Vyshnevskyy V. I., 2000 - Rivers and waterbodies of Ukraine, State and usage, Kiev, Ukraine, Vinol, 376. (in Ukrainian)

59. Wehr J. D. and Descy J.-P., 1998 - Use of phytoplankton in large river management, Journal of Phycology, 34, 741-749.

60. *** The Directive 2000/60/EP of the European Parliament and of the Council establishing a framework for community action in the field of water policy, OJL, 327. 
Appendix 1: The phytoplankton abundance (upper: thousand cells $\mathrm{l}^{-1}$ ) and biomass (bottom: $\mathrm{mg} \mathrm{l}^{-1}$ ) of the Southern Bug River (Khmelnitsky monitoring station) in 2010-2011.

\begin{tabular}{|c|c|c|c|c|c|c|c|c|c|c|c|c|}
\hline \multirow{2}{*}{\multicolumn{13}{|c|}{$\begin{array}{c}\text { Taxa } \\
\text { Bacillariophyta }\end{array}$}} \\
\hline & & & & & & & & & & & & \\
\hline $\begin{array}{l}\text { Achnanthidium } \\
\text { minutissima } \\
\text { (Kütz.) Czarn. }\end{array}$ & - & - & $\begin{array}{c}\underline{4} \\
0.00 \\
1\end{array}$ & $\begin{array}{c}\underline{5} \\
0.00 \\
1\end{array}$ & $\frac{30}{0.00}$ & - & - & $\begin{array}{c}\frac{40}{0.00} \\
4\end{array}$ & - & - & - & - \\
\hline $\begin{array}{l}\text { Amphora ovalis } \\
\text { (Kütz.) Kütz. }\end{array}$ & - & - & - & - & $\begin{array}{c}0.01 \\
0.01 \\
5\end{array}$ & - & $\begin{array}{c}\frac{21}{21} \\
0.05 \\
2\end{array}$ & $\begin{array}{c}\underline{4} \\
0.01\end{array}$ & - & - & - & - \\
\hline $\begin{array}{l}\text { Aulacoseira } \\
\text { granulata } \\
\text { (Ehrenb.) } \\
\text { Simonsen var. } \\
\text { granulata } \\
\end{array}$ & - & $\begin{array}{l}\frac{7}{7} \\
0.00 \\
8\end{array}$ & $\frac{12}{0.01}$ & - & - & $\frac{\frac{903}{1.08}}{3}$ & $\begin{array}{c}\frac{35}{0.04} \\
2\end{array}$ & - & $\begin{array}{c}\frac{131}{2} \\
\frac{2}{57} \\
4\end{array}$ & - & - & - \\
\hline $\begin{array}{l}\text { Cocconeis } \\
\text { placentula } \\
\text { Ehrenb. }\end{array}$ & - & - & $\begin{array}{c}\underline{4} \\
0.00 \\
8\end{array}$ & - & - & - & - & $\begin{array}{c}\frac{12}{0.02} \\
6\end{array}$ & - & - & - & - \\
\hline $\begin{array}{l}\text { Cyclostephanos } \\
\text { dubius (Fricke) } \\
\text { Round }\end{array}$ & $\begin{array}{c}0.00 \\
5\end{array}$ & $\begin{array}{c}\frac{3.5}{0.00} \\
3\end{array}$ & - & - & - & - & - & - & - & - & - & $\begin{array}{l}\frac{15}{0.01} \\
6\end{array}$ \\
\hline $\begin{array}{l}\text { Cyclostephanos } \\
\text { invisitatus (Hohn } \\
\text { and Hellermann) } \\
\text { Theriot. Stoermer } \\
\text { and Håkasson }\end{array}$ & - & - & - & - & - & - & - & - & - & $\begin{array}{c}0.00 \\
3\end{array}$ & - & - \\
\hline $\begin{array}{l}\text { Cyclotella } \\
\text { meneghiniana } \\
\text { Kütz. }\end{array}$ & - & - & - & - & $\begin{array}{c}\underline{6} \\
0.00 \\
6\end{array}$ & - & - & - & $\begin{array}{c}4 \\
0.00 \\
4\end{array}$ & - & - & - \\
\hline $\begin{array}{l}\text { Cymbella } \\
\text { lanceolata (C. } \\
\text { Agardh) Ehrenb. }\end{array}$ & - & - & - & - & - & $\frac{70}{0.55}$ & - & - & - & - & - & - \\
\hline $\begin{array}{l}\text { Diatoma mesodon } \\
\text { (Ehrenb.) Kütz. }\end{array}$ & - & $\begin{array}{c}\frac{3.5}{0.00} \\
4\end{array}$ & - & - & - & - & - & - & - & - & - & - \\
\hline $\begin{array}{l}\text { Encyonema } \\
\text { caespitosum } \\
\text { Kütz. }\end{array}$ & - & - & - & - & - & - & $\begin{array}{c}\frac{7}{7} \\
0.01 \\
2\end{array}$ & - & - & - & - & - \\
\hline $\begin{array}{l}\text { Encyonema } \\
\text { minuta (Hilse ex } \\
\text { Rabenh.) D. G. } \\
\text { Mann }\end{array}$ & - & - & - & - & - & $\begin{array}{c}\frac{7}{2} \\
5\end{array}$ & - & - & - & - & - & - \\
\hline $\begin{array}{l}\text { Fragilaria } \\
\text { crotonensis Kitton }\end{array}$ & - & - & - & - & - & - & $\begin{array}{c}\frac{28}{0.00} \\
2\end{array}$ & $\begin{array}{c}\frac{16}{0.00} \\
2\end{array}$ & - & - & - & - \\
\hline $\begin{array}{l}\text { Gomphonema } \\
\text { clavatum Ehrenb. }\end{array}$ & - & - & - & - & - & - & - & - & - & - & $\begin{array}{c}4 \\
0.00 \\
1\end{array}$ & - \\
\hline
\end{tabular}


Appendix 1 (continuing): The phytoplankton abundance (upper: thousand cells $\mathrm{l}^{-1}$ ) and biomass (bottom: $\mathrm{mg} \mathrm{l}^{-1}$ ) of the Southern Bug River (Khmelnitsky monitoring station) in 20102011.

\begin{tabular}{|c|c|c|c|c|c|c|c|c|c|c|c|c|}
\hline Taxa & I & II & III & IV & $\mathrm{V}$ & VI & VII & VIII & IX & $X$ & $\mathrm{XI}$ & XII \\
\hline $\begin{array}{l}\text { Gomphonema } \\
\text { minutum } \\
\text { (C. Agardh) } \\
\text { C. Agardh }\end{array}$ & - & - & - & $\begin{array}{c}0.00 \\
2\end{array}$ & - & - & - & $\begin{array}{c}\frac{4}{00} \\
1\end{array}$ & - & - & - & - \\
\hline $\begin{array}{l}\text { Melosira varians } \\
\text { C. Agardh }\end{array}$ & - & - & $\begin{array}{c}\frac{20}{0.13} \\
2\end{array}$ & - & - & $\begin{array}{c}\frac{826}{5.45} \\
1\end{array}$ & - & - & $\begin{array}{c}\frac{32}{0.21} \\
1\end{array}$ & - & - & - \\
\hline $\begin{array}{l}\text { Navicula } \\
\text { cryptotenella } \\
\text { Lange-Bert. }\end{array}$ & - & - & $\begin{array}{c}\frac{16}{0.00} \\
6\end{array}$ & - & - & $\begin{array}{c}\frac{21}{0.00} \\
6\end{array}$ & - & - & - & - & $\begin{array}{c}\underline{4} \\
0.00 \\
1\end{array}$ & - \\
\hline $\begin{array}{l}\text { Navicula } \\
\text { tripunctata (O. F. } \\
\text { Müll.) Bory }\end{array}$ & - & - & - & - & $\begin{array}{c}\underline{6} \\
0.00 \\
3\end{array}$ & - & - & - & - & - & - & - \\
\hline $\begin{array}{l}\text { Stephanodiscus } \\
\text { hantzschii Grunow }\end{array}$ & $\begin{array}{c}0.00 \\
6\end{array}$ & - & - & - & - & $\begin{array}{c}\underline{14} \\
0.01 \\
6 \\
\end{array}$ & - & - & - & - & $\begin{array}{c}\underline{4} \\
0.00 \\
4 \\
\end{array}$ & - \\
\hline $\begin{array}{l}\text { Ulnaria acus } \\
\text { (Kütz.) Aboal }\end{array}$ & - & - & - & - & - & - & - & $\begin{array}{c}\frac{16}{0.00} \\
9\end{array}$ & $\begin{array}{c}0.00 \\
2\end{array}$ & - & - & - \\
\hline $\begin{array}{l}\text { Ulnaria ulna } \\
\text { (Nitzsch) } \\
\text { Compere }\end{array}$ & - & - & $\underline{0} \underline{8}^{0.04}$ & - & $\begin{array}{c}\frac{48}{0.24} \\
4\end{array}$ & - & - & - & - & - & - & - \\
\hline \multicolumn{13}{|l|}{ Chlorophyta } \\
\hline $\begin{array}{l}\text { Actinastrum } \\
\text { hantzschii Lagerh. } \\
\text { var. hantzschii }\end{array}$ & - & - & - & - & - & - & - & $\begin{array}{c}\underline{64} \\
0.01 \\
9\end{array}$ & - & - & - & - \\
\hline $\begin{array}{l}\text { Actinastrum } \\
\text { hantzschii var. } \\
\text { subtile Wołosz. }\end{array}$ & - & - & - & - & - & - & $\begin{array}{c}\underline{56} \\
0.01 \\
6\end{array}$ & - & - & - & - & - \\
\hline $\begin{array}{l}\text { Acutodesmus } \\
\text { obliquus (Turpin) } \\
\text { P. Tsarenko }\end{array}$ & - & - & - & - & - & - & - & $\begin{array}{c}\frac{32}{0.01} \\
3\end{array}$ & - & - & - & - \\
\hline $\begin{array}{l}\text { Acutodesmus } \\
\text { pectinatus } \\
\text { (Meyen) P. } \\
\text { Tsarenko var. } \\
\text { pectinatus }\end{array}$ & - & - & - & - & - & $\begin{array}{c}\frac{35}{0.02} \\
1\end{array}$ & $\begin{array}{c}\frac{28}{0.01} \\
6\end{array}$ & $\begin{array}{c}\frac{16}{0.00} \\
9\end{array}$ & - & - & - & - \\
\hline $\begin{array}{l}\text { Coelastrum } \\
\text { astroideum De } \\
\text { Not. }\end{array}$ & - & - & - & - & - & $\frac{140}{0.14}$ & $\begin{array}{c}\frac{336}{0.03} \\
3\end{array}$ & $\begin{array}{c}\frac{132}{0.13} \\
2\end{array}$ & $\begin{array}{c}\frac{36}{0.03} \\
6\end{array}$ & - & - & - \\
\hline $\begin{array}{l}\text { Coelastrum } \\
\text { microporum } \\
\text { Nägeli }\end{array}$ & - & - & - & - & - & - & $\begin{array}{c}\frac{154}{0.04} \\
1\end{array}$ & $\begin{array}{c}\frac{72}{0.01} \\
9\end{array}$ & - & - & - & - \\
\hline
\end{tabular}


Appendix 1 (continuing): The phytoplankton abundance (upper: thousand cells $\mathrm{l}^{-1}$ ) and biomass (bottom: $\mathrm{mg} \mathrm{l}^{-1}$ ) of the Southern Bug River (Khmelnitsky monitoring station) in 20102011.

\begin{tabular}{|c|c|c|c|c|c|c|c|c|c|c|c|c|}
\hline Taxa & I & II & III & IV & $\mathrm{V}$ & VI & VII & VIII & IX & $\mathrm{X}$ & $\mathrm{XI}$ & XII \\
\hline $\begin{array}{l}\text { Coenococcus } \\
\text { polycoccus } \\
\text { (Korschikov) } \\
\text { Hindák } \\
\end{array}$ & - & - & - & - & - & $\begin{array}{l}\frac{84}{0.17} \\
6\end{array}$ & - & - & - & - & - & - \\
\hline $\begin{array}{l}\text { Crucigenia } \\
\text { tetrapedia } \\
\text { (Kirchn.) West } \\
\text { and G. S. West }\end{array}$ & - & - & - & - & $\begin{array}{c}\frac{18}{0.00} \\
1\end{array}$ & $\begin{array}{c}\frac{98}{0.00} \\
1\end{array}$ & $\begin{array}{c}\underline{35} \\
0.00 \\
1\end{array}$ & $\begin{array}{c}\frac{32}{0.00} \\
1\end{array}$ & $\begin{array}{c}\frac{40}{0.00} \\
1\end{array}$ & $\begin{array}{c}\frac{24}{0.00} \\
1\end{array}$ & $\begin{array}{c}\underline{4} \\
0.00 \\
1\end{array}$ & - \\
\hline $\begin{array}{l}\text { Crucigeniella } \\
\text { apiculata } \\
\text { (Lemmerm.) } \\
\text { Komárek } \\
\end{array}$ & - & - & - & - & - & - & $\begin{array}{c}\frac{504}{0.15} \\
1\end{array}$ & $\begin{array}{c}\frac{208}{0.06} \\
2\end{array}$ & $\begin{array}{c}\frac{60}{0.01} \\
8\end{array}$ & - & - & - \\
\hline $\begin{array}{l}\text { Desmodesmus } \\
\text { armatus (Chodat) } \\
\text { E. Hegew. }\end{array}$ & - & - & $\begin{array}{c}\underline{4} \\
0.00 \\
2\end{array}$ & - & $\begin{array}{c}\frac{12}{0.00} \\
8\end{array}$ & $\begin{array}{c}\underline{56} \\
0.00 \\
9\end{array}$ & $\begin{array}{c}\frac{28}{0.00} \\
4\end{array}$ & - & - & - & - & - \\
\hline $\begin{array}{l}\text { Desmodesmus } \\
\text { bicaudatus } \\
\text { (Dedus.) P. } \\
\text { Tsarenko. }\end{array}$ & - & - & - & - & - & - & $\begin{array}{c}\frac{70}{0.00} \\
9\end{array}$ & $\begin{array}{c}\frac{16}{0.00} \\
2\end{array}$ & - & - & - & - \\
\hline $\begin{array}{l}\text { Desmodesmus } \\
\text { brasiliensis } \\
\text { (Bohlin) E. } \\
\text { Hegew. }\end{array}$ & - & - & - & - & - & - & $\begin{array}{c}\frac{56}{0.02} \\
2\end{array}$ & - & - & - & - & - \\
\hline $\begin{array}{l}\text { Desmodesmus } \\
\text { communis (E. } \\
\text { Hegew.) E. } \\
\text { Hegew. var. } \\
\text { communis }\end{array}$ & - & - & - & $\begin{array}{c}\frac{20}{0.00} \\
5\end{array}$ & $\begin{array}{c}\frac{24}{0.00} \\
6\end{array}$ & $\begin{array}{c}\frac{28}{0.00} \\
7\end{array}$ & $\begin{array}{c}\frac{28}{0.00} \\
7\end{array}$ & $\begin{array}{c}\frac{32}{0.00} \\
8\end{array}$ & $\begin{array}{c}\frac{16}{0.00} \\
4\end{array}$ & $\begin{array}{c}\underline{6} \\
0.00 \\
1\end{array}$ & - & - \\
\hline $\begin{array}{l}\text { Desmodesmus } \\
\text { costato-granulatus } \\
\text { (Skuja) E. Hegew. }\end{array}$ & - & - & - & $\begin{array}{c}\frac{10}{0.00} \\
3\end{array}$ & $\begin{array}{c}\underline{12} \\
0.00 \\
3\end{array}$ & $\begin{array}{c}\underline{42} \\
0.01 \\
2\end{array}$ & - & - & - & $\begin{array}{c}\underline{6} .00 \\
1\end{array}$ & - & - \\
\hline $\begin{array}{l}\text { Desmodesmus } \\
\text { denticulatus } \\
\text { (Lagerh.) An. } \\
\text { Friedl and E. } \\
\text { Hegew. }\end{array}$ & - & - & - & - & - & $\begin{array}{c}\frac{84}{0.01} \\
6\end{array}$ & $\begin{array}{c}\frac{28}{0.00} \\
5\end{array}$ & - & - & - & - & - \\
\hline $\begin{array}{l}\text { Desmodesmus } \\
\text { intermedius } \\
\text { (Chodat) E. } \\
\text { Hegew. var. } \\
\text { acutispinus (Y. V. } \\
\text { Roll) E. Hegew. }\end{array}$ & - & - & - & - & - & $\begin{array}{c}\underline{28} \\
0.00 \\
1\end{array}$ & - & - & - & - & - & - \\
\hline
\end{tabular}


Appendix 1 (continuing): The phytoplankton abundance (upper: thousand cells $\mathrm{l}^{-1}$ ) and biomass (bottom: $\mathrm{mg} \mathrm{l}^{-1}$ ) of the Southern Bug River (Khmelnitsky monitoring station) in 20102011.

\begin{tabular}{|c|c|c|c|c|c|c|c|c|c|c|c|c|}
\hline Таха & I & II & III & IV & $\mathrm{V}$ & VI & VII & VIII & IX & $\mathrm{X}$ & XI & XII \\
\hline $\begin{array}{l}\text { Desmodesmus } \\
\text { lefevrei } \\
\text { (Deflandre) A. } \\
\text { Fridl and E. Hege. }\end{array}$ & - & - & - & - & - & $\begin{array}{c}\frac{28}{0.00} \\
8\end{array}$ & - & - & - & - & - & - \\
\hline $\begin{array}{l}\text { Desmodesmus } \\
\text { subspicatus } \\
\text { (Chodat) E. } \\
\text { Hegew. and A. } \\
\text { Schmidt var. } \\
\text { subspicatus }\end{array}$ & - & - & - & - & $\begin{array}{c}\frac{24}{0.00} \\
7\end{array}$ & - & - & - & - & - & - & - \\
\hline $\begin{array}{l}\text { Dictyosphaerium } \\
\text { granulatum } \\
\text { Hindák } \\
\end{array}$ & - & - & - & - & - & - & $\begin{array}{c}\underline{56} \\
0.00 \\
2\end{array}$ & - & - & - & - & - \\
\hline $\begin{array}{l}\text { Dictyosphaerium } \\
\text { pulchellum Wood }\end{array}$ & - & - & - & - & - & $\begin{array}{c}0.04 \\
0.00 \\
4\end{array}$ & - & - & - & - & - & - \\
\hline $\begin{array}{l}\text { Enallax } \\
\text { acutiformis } \\
\text { (Schröd.) Hindák } \\
\text { var. acutiformis }\end{array}$ & - & - & - & - & - & - & - & - & $\begin{array}{c}\frac{16}{0.00} \\
9\end{array}$ & - & - & - \\
\hline $\begin{array}{l}\text { Enallax } \\
\text { acutiformis } \\
\text { (Schröd.) Hindák } \\
\text { var. costatus } \\
\text { (Hub.-Pest.) P. } \\
\text { Tsarenko }\end{array}$ & - & - & - & - & - & - & $\begin{array}{c}\frac{28}{0.00} \\
8\end{array}$ & - & - & - & - & - \\
\hline $\begin{array}{l}\text { Granulocystopsis } \\
\text { coronata } \\
\text { (Lemmerm.) } \\
\text { Hindák }\end{array}$ & - & - & - & - & - & - & $\begin{array}{c}\frac{7}{7} \\
1\end{array}$ & - & - & - & - & - \\
\hline $\begin{array}{l}\text { Kirchneriella } \\
\text { lunaris (Kirchn.) } \\
\text { Moeb. }\end{array}$ & - & - & - & - & - & $\begin{array}{c}\frac{14}{14} \\
0.00 \\
1\end{array}$ & $\begin{array}{c}\frac{7}{700} \\
1\end{array}$ & - & - & $\begin{array}{c}\underline{3} \\
0.00 \\
1\end{array}$ & $\begin{array}{c}0.00 \\
1\end{array}$ & - \\
\hline $\begin{array}{l}\text { Koliella longiseta } \\
\text { (Vischer) Hindák }\end{array}$ & - & - & - & - & - & $\begin{array}{c}0.00 \\
0.00 \\
1\end{array}$ & - & - & - & - & - & $\begin{array}{c}\frac{15}{0.00} \\
1\end{array}$ \\
\hline $\begin{array}{l}\text { Lagerheimia } \\
\text { wratislaviensis } \\
\text { Schröd. }\end{array}$ & - & - & - & - & - & - & $\begin{array}{c}\frac{7}{0.00} \\
1\end{array}$ & - & - & - & - & - \\
\hline $\begin{array}{l}\text { Micractinium } \\
\text { pusillum Fresen. }\end{array}$ & - & - & - & - & - & - & - & - & - & - & - & $\begin{array}{c}\frac{20}{0.00} \\
1\end{array}$ \\
\hline $\begin{array}{l}\text { Monactinus } \\
\text { simplex (Meyen) } \\
\text { Corda }\end{array}$ & - & - & - & - & - & - & - & $\begin{array}{l}\frac{4}{4} \\
2\end{array}$ & - & - & - & - \\
\hline
\end{tabular}


Appendix 1 (continuing): The phytoplankton abundance (upper: thousand cells $\mathrm{l}^{-1}$ ) and biomass (bottom: $\mathrm{mg} \mathrm{l}^{-1}$ ) of the Southern Bug River (Khmelnitsky monitoring station) in 20102011.

\begin{tabular}{|c|c|c|c|c|c|c|c|c|c|c|c|c|}
\hline Taxa & I & II & III & IV & $\mathrm{V}$ & VI & VII & VIII & IX & $\mathrm{X}$ & XI & XII \\
\hline $\begin{array}{l}\text { Monactinus } \\
\text { simplex (Meyen) } \\
\text { Corda var. } \\
\text { echinulatum } \\
\text { (Wittr.) P. } \\
\text { Tsarenko }\end{array}$ & - & - & - & - & - & - & - & $\frac{32}{0.01}$ & - & - & - & - \\
\hline $\begin{array}{l}\text { Monoraphidium } \\
\text { arcuatum } \\
\text { (Korschikov) } \\
\text { Hindák }\end{array}$ & - & - & $\begin{array}{c}\frac{12}{0.00} \\
2\end{array}$ & - & $\begin{array}{c}\frac{12}{0.00} \\
2\end{array}$ & $\begin{array}{c}\underline{7} \\
0.00 \\
1\end{array}$ & - & - & $\begin{array}{c}\underline{4} \\
0.00 \\
1\end{array}$ & $\begin{array}{c}\underline{6} \\
0.00 \\
1\end{array}$ & - & $\begin{array}{c}\underline{5} \\
0.00 \\
1\end{array}$ \\
\hline $\begin{array}{l}\text { Monoraphidium } \\
\text { griffithii (Berk.) } \\
\text { Komárk.-Legn. }\end{array}$ & - & - & $\begin{array}{c}\underline{8} \\
0.00 \\
1\end{array}$ & $\begin{array}{c}\underline{10} \\
0.00 \\
1\end{array}$ & $\begin{array}{c}\underline{6} \\
0.00 \\
1\end{array}$ & $\frac{35}{0.00}$ & $\begin{array}{c}\frac{70}{0.00} \\
7\end{array}$ & $\begin{array}{c}\underline{12} \\
0.00 \\
1\end{array}$ & - & $\begin{array}{c}0.00 \\
1\end{array}$ & - & $\begin{array}{c}0.00 \\
1\end{array}$ \\
\hline $\begin{array}{l}\text { Monoraphidium } \\
\text { minutum (Nägeli) } \\
\text { Komárk.-Legn. }\end{array}$ & - & - & $\begin{array}{c}\underline{8} \\
0.00 \\
1\end{array}$ & $\begin{array}{c}\underline{5} \\
0.00 \\
1\end{array}$ & $\begin{array}{c}\underline{6} \\
0.00 \\
1\end{array}$ & - & $\begin{array}{c}\frac{21}{0.00} \\
1\end{array}$ & $\begin{array}{c}\frac{4}{4} \\
0.00 \\
1\end{array}$ & - & - & - & $\begin{array}{c}\underline{5} \\
0.00 \\
1\end{array}$ \\
\hline $\begin{array}{l}\text { Oocystis lacustris } \\
\text { Chodat }\end{array}$ & - & - & - & - & - & - & $\frac{49}{0.02}$ & - & - & - & - & - \\
\hline $\begin{array}{l}\text { Pediastrum duplex } \\
\text { Meyen var. duplex }\end{array}$ & - & - & - & - & - & - & $\frac{98}{0.02}$ & $\frac{64}{0.02}$ & - & - & - & - \\
\hline $\begin{array}{l}\text { Pediastrum duplex } \\
\text { var. } \\
\text { subgranulatum } \\
\text { Racib. }\end{array}$ & - & - & - & - & - & - & $\frac{98}{0.02}$ & - & - & - & - & - \\
\hline $\begin{array}{l}\text { Pseudopediastrum } \\
\text { boryanum } \\
\text { (Turpin) E. } \\
\text { Hegew. }\end{array}$ & - & - & - & - & - & - & - & $\begin{array}{l}\frac{60}{0.01} \\
2\end{array}$ & - & - & - & - \\
\hline $\begin{array}{l}\text { Pseudopediastrum } \\
\text { boryanum var. } \\
\text { longicorne } \\
\text { (Reinsch) P. } \\
\text { Tsarenko }\end{array}$ & - & - & - & - & - & - & $\frac{49}{0.02}$ & - & - & - & - & - \\
\hline $\begin{array}{l}\text { Raphidocelis } \\
\text { sigmoidea Hindak }\end{array}$ & - & - & - & $\begin{array}{c}0.00 \\
0.5 \\
1\end{array}$ & - & - & - & - & - & - & - & - \\
\hline $\begin{array}{l}\text { Scenedesmus } \\
\text { ellipticus Corda }\end{array}$ & - & - & - & - & $\begin{array}{c}\underline{24} \\
0.00 \\
9\end{array}$ & - & - & $\begin{array}{c}\frac{16}{0.00} \\
6\end{array}$ & - & - & - & - \\
\hline $\begin{array}{l}\text { Scenedesmus } \\
\text { obtusus Meyen } \\
\text { var. obtusus }\end{array}$ & - & - & - & - & - & $\frac{28}{0.01}$ & - & - & - & - & - & - \\
\hline
\end{tabular}


Appendix 1 (continuing): The phytoplankton abundance (upper: thousand cells $\mathrm{l}^{-1}$ ) and biomass (bottom: $\mathrm{mg} \mathrm{l}^{-1}$ ) of the Southern Bug River (Khmelnitsky monitoring station) in 20102011.

\begin{tabular}{|c|c|c|c|c|c|c|c|c|c|c|c|c|}
\hline Таха & I & II & III & IV & $\mathrm{V}$ & VI & VII & VIII & IX & $\mathrm{X}$ & XI & XII \\
\hline $\begin{array}{l}\text { Tetraedron } \\
\text { minimum (A. } \\
\text { Braun) Hansg. }\end{array}$ & - & - & - & - & - & $\begin{array}{c}\underline{63} \\
0.01 \\
8\end{array}$ & $\begin{array}{c}\frac{70}{0.02} \\
1\end{array}$ & $\begin{array}{c}\frac{12}{0.00} \\
4\end{array}$ & $\begin{array}{c}\frac{4}{00} \\
1\end{array}$ & - & - & - \\
\hline $\begin{array}{l}\text { Tetraedron } \\
\text { triangulare } \\
\text { Korschikov }\end{array}$ & - & - & - & - & - & $\begin{array}{c}\frac{28}{0.01} \\
4\end{array}$ & - & - & - & - & - & - \\
\hline $\begin{array}{l}\text { Tetrastrum } \\
\text { staurogeniaeforme } \\
\text { (Schröd.) } \\
\text { Lemmerm. }\end{array}$ & - & - & - & - & - & - & - & - & - & $\begin{array}{c}\frac{12}{0.00} \\
1\end{array}$ & - & - \\
\hline $\begin{array}{l}\text { Tetrastrum } \\
\text { triangulare } \\
\text { (Chodat) Komárek }\end{array}$ & - & - & $\begin{array}{c}\frac{48}{0.02} \\
4\end{array}$ & - & - & $\begin{array}{c}\frac{112}{0.05} \\
6\end{array}$ & - & $\begin{array}{l}\frac{64}{0.03} \\
2\end{array}$ & - & $\frac{48}{0.02}$ & - & - \\
\hline $\begin{array}{l}\text { Treubaria } \\
\text { triappendiculata } \\
\text { C. Bernard }\end{array}$ & - & - & - & - & - & - & - & $\begin{array}{c}\frac{4}{0.00} \\
1\end{array}$ & - & - & - & - \\
\hline $\begin{array}{l}\text { Westella } \\
\text { botryoides (W. } \\
\text { West) De Wild. }\end{array}$ & - & - & - & - & - & - & $\begin{array}{c}\frac{28}{0.00} \\
5\end{array}$ & - & - & - & - & - \\
\hline \multicolumn{13}{|l|}{ Chrysophyta } \\
\hline $\begin{array}{l}\text { Dinobryon } \\
\text { divergens Imhof }\end{array}$ & - & - & - & - & - & $\begin{array}{c}0.7 \\
0.02 \\
5\end{array}$ & - & - & - & - & - & - \\
\hline $\begin{array}{l}\text { Pseudokephyrion } \\
\text { cylindricum } \\
\text { (Lackey) Bourr. }\end{array}$ & $\begin{array}{c}0.00 \\
1\end{array}$ & $\begin{array}{c}\frac{14}{0.00} \\
4\end{array}$ & - & $\frac{35}{0.01}$ & $\begin{array}{c}\underline{30} \\
0.00 \\
9\end{array}$ & - & - & - & - & $\frac{78}{0.02}$ & $\begin{array}{c}\frac{16}{0.00} \\
4\end{array}$ & $\begin{array}{c}\frac{10}{0.00} \\
3\end{array}$ \\
\hline $\begin{array}{l}\text { Pseudokephyrion } \\
\text { latum (J. Schiller) } \\
\text { W. G. G. Schmid }\end{array}$ & - & - & - & - & - & $\begin{array}{l}\frac{7}{7} \\
2\end{array}$ & - & - & - & - & - & - \\
\hline $\begin{array}{l}\text { Pseudokephyrion } \\
\text { schilleri } \\
\text { (J. Schiller) } \\
\text { W. Conrad }\end{array}$ & - & - & - & - & - & $\begin{array}{c}\frac{7}{7} \\
2\end{array}$ & - & - & - & - & - & - \\
\hline \multicolumn{13}{|l|}{ Cyanoprokaryota } \\
\hline $\begin{array}{l}\text { Aphanizomenon } \\
\text { elenkinii Kisselev }\end{array}$ & - & - & - & - & - & - & $\begin{array}{c}\frac{371}{4} \\
0.29 \\
6\end{array}$ & $\begin{array}{c}\frac{76}{0.00} \\
6\end{array}$ & - & - & - & - \\
\hline $\begin{array}{l}\text { Aphanizomenon } \\
\text { flos-aquae (L.) } \\
\text { Ralfs ex Bornet } \\
\text { and Flahault }\end{array}$ & - & - & - & $\begin{array}{c}\frac{600}{0.04} \\
8\end{array}$ & - & - & $\begin{array}{c}\frac{338}{8} \\
0.27 \\
1\end{array}$ & $\begin{array}{c}\frac{136}{0.01} \\
1\end{array}$ & - & - & - & - \\
\hline
\end{tabular}


Appendix 1 (continuing): The phytoplankton abundance (upper: thousand cells $\mathrm{l}^{-1}$ ) and biomass (bottom: $\mathrm{mg} \mathrm{l}^{-1}$ ) of the Southern Bug River (Khmelnitsky monitoring station) in 20102011.

\begin{tabular}{|c|c|c|c|c|c|c|c|c|c|c|c|c|}
\hline Taxa & I & II & III & IV & $\mathrm{V}$ & VI & VII & VIII & IX & $\mathrm{X}$ & $\mathrm{XI}$ & XII \\
\hline $\begin{array}{l}\text { Aphanocapsa } \\
\text { planctonica (G. } \\
\text { M. S.) Komárek } \\
\text { and Anagn. }\end{array}$ & - & - & - & - & - & $\begin{array}{c}\frac{105}{0.00} \\
2\end{array}$ & - & - & - & - & - & - \\
\hline $\begin{array}{l}\text { Dolichospermum } \\
\text { flos-aquae } \\
\text { (Lyngb.) Wacklin. } \\
\text { Hoffmann and } \\
\text { Komarek }\end{array}$ & - & - & - & - & - & $\begin{array}{c}\frac{112}{0.00} \\
8\end{array}$ & $\begin{array}{l}\frac{378}{0} \\
0.30 \\
2\end{array}$ & $\begin{array}{c}\frac{52}{0.00} \\
4\end{array}$ & $\begin{array}{c}\frac{84}{0.00} \\
6\end{array}$ & - & - & - \\
\hline $\begin{array}{l}\text { Microcystis } \\
\text { aeruginosa (Kütz.) } \\
\text { Kütz. }\end{array}$ & - & - & - & - & $\begin{array}{c}\frac{90}{0.00} \\
5\end{array}$ & - & $\begin{array}{c}\frac{280}{0.01} \\
6\end{array}$ & - & - & - & - & - \\
\hline $\begin{array}{l}\text { Microcystis firma } \\
\text { (Bréb. and Lenor.) } \\
\text { Schmidle }\end{array}$ & - & - & - & - & - & - & - & $\frac{772}{0.01}$ & - & - & - & - \\
\hline $\begin{array}{l}\text { Oscillatoria } \\
\text { amphibia J. } \\
\text { Agardh ex } \\
\text { Gomont }\end{array}$ & - & - & - & - & $\begin{array}{c}\frac{168}{0.01} \\
6\end{array}$ & - & - & $\begin{array}{c}\frac{196}{0.00} \\
2\end{array}$ & $\begin{array}{c}\underline{80} \\
0.00 \\
1\end{array}$ & - & - & - \\
\hline $\begin{array}{l}\text { Oscillatoria tenuis } \\
\text { Agardh ex } \\
\text { Gomont }\end{array}$ & - & - & - & $\begin{array}{l}\frac{50}{0.00} \\
5\end{array}$ & $\begin{array}{c}\frac{60}{0.00} \\
6\end{array}$ & - & - & - & $\begin{array}{c}\frac{160}{0.01} \\
6\end{array}$ & - & - & - \\
\hline \multicolumn{13}{|l|}{ Dinophyta } \\
\hline $\begin{array}{l}\text { Ceratium } \\
\text { hirundinella (O. } \\
\text { Müll.) Bergh }\end{array}$ & - & - & - & - & - & $\begin{array}{c}\frac{7}{21} \\
4\end{array}$ & $\begin{array}{c}\frac{77}{2.35} \\
5\end{array}$ & $\begin{array}{c}\frac{12}{0.36} \\
7\end{array}$ & $\begin{array}{c}\frac{104}{3.18} \\
2\end{array}$ & - & - & - \\
\hline $\begin{array}{l}\text { Gymnodinium } \\
\text { paradoxum A. J. } \\
\text { Schill } \\
\end{array}$ & - & - & - & $\begin{array}{c}\frac{10}{0.13} \\
6\end{array}$ & - & - & - & $\begin{array}{c}\frac{4}{4} \\
4\end{array}$ & $\begin{array}{c}\frac{4}{4} \\
4\end{array}$ & - & - & - \\
\hline $\begin{array}{l}\text { Peridiniopsis } \\
\text { polonicum } \\
\text { (Wołosz.) Bourr. }\end{array}$ & - & - & - & - & - & $\begin{array}{c}\frac{21}{0.27} \\
7\end{array}$ & - & - & $\begin{array}{c}\underline{4} \\
0.05 \\
2\end{array}$ & $\begin{array}{c}\underline{3} \\
0.03 \\
9\end{array}$ & - & - \\
\hline $\begin{array}{l}\text { Peridinium } \\
\text { aciculiferum } \\
\text { Lemmerm. }\end{array}$ & - & - & - & - & - & - & $\frac{7}{17}$ & $\begin{array}{c}\frac{12}{0.29} \\
3\end{array}$ & - & - & - & $\begin{array}{c}\frac{5}{12} \\
2\end{array}$ \\
\hline \multicolumn{13}{|l|}{ Euglenophyta } \\
\hline $\begin{array}{l}\text { Euglena acus } \\
\text { Ehrenb. }\end{array}$ & - & - & - & - & $\begin{array}{c}0.6 \\
0.00 \\
6 \\
\end{array}$ & - & $\begin{array}{c}\frac{7}{7} \\
0.00 \\
7\end{array}$ & - & - & - & - & $\begin{array}{c}5 \underline{5} \\
0.00 \\
5 \\
\end{array}$ \\
\hline $\begin{array}{l}\text { Euglena granulata } \\
\text { (G. A. Klebs) } \\
\text { Schmitz }\end{array}$ & - & - & - & $\begin{array}{c}\underline{5} \\
0.02 \\
7\end{array}$ & - & - & - & - & - & - & - & - \\
\hline
\end{tabular}


Appendix 1 (continuing): The phytoplankton abundance (upper: thousand cells $\mathrm{l}^{-1}$ ) and biomass (bottom: $\mathrm{mg} \mathrm{l}^{-1}$ ) of the Southern Bug River (Khmelnitsky monitoring station) in 20102011.

\begin{tabular}{|c|c|c|c|c|c|c|c|c|c|c|c|c|}
\hline Таха & I & II & III & IV & $\mathrm{V}$ & VI & VII & VIII & IX & $X$ & XI & XII \\
\hline $\begin{array}{l}\text { Euglena oblonga } \\
\text { Schmitz }\end{array}$ & - & - & $\begin{array}{c}\frac{4}{6} 8 \\
2\end{array}$ & - & - & - & - & - & - & - & - & - \\
\hline $\begin{array}{l}\text { Lepocinclis } \\
\text { fusiformis (Carter) } \\
\text { Lemmerm. }\end{array}$ & - & - & - & - & - & - & $\begin{array}{c}\frac{14}{0.09} \\
6\end{array}$ & - & - & - & - & - \\
\hline $\begin{array}{l}\text { Phacus } \\
\text { acuminatus A. } \\
\text { Stokes }\end{array}$ & - & - & - & - & - & $\underline{14}$ & - & - & - & - & - & - \\
\hline $\begin{array}{l}\text { Phacus } \\
\text { curvicauda } \\
\text { Svirenko }\end{array}$ & - & - & $\begin{array}{c}\underline{4} \\
0.01 \\
5\end{array}$ & - & - & - & $\begin{array}{c}\frac{7}{72} \\
6\end{array}$ & - & - & - & - & - \\
\hline $\begin{array}{l}\text { Phacus longicauda } \\
\text { (Ehrenb.) Dujard. } \\
\text { var. longicauda f. } \\
\text { longicauda }\end{array}$ & - & - & - & - & - & $\begin{array}{c}\frac{7}{01} \\
9\end{array}$ & $\begin{array}{c}\frac{14}{0.03} \\
9\end{array}$ & $\begin{array}{c}\underline{4} \\
0.01 \\
1\end{array}$ & - & - & - & - \\
\hline $\begin{array}{l}\text { Phacus orbicularis } \\
\text { Hübner }\end{array}$ & - & - & - & - & - & - & $\begin{array}{c}\frac{21}{0.25} \\
4\end{array}$ & - & - & - & - & - \\
\hline $\begin{array}{l}\text { Trachelomonas } \\
\text { nigra Swir. }\end{array}$ & - & - & - & $\begin{array}{c}\frac{10}{0.03} \\
6 \\
\end{array}$ & $\begin{array}{c}\frac{12}{0.04} \\
3\end{array}$ & $\begin{array}{c}\frac{7}{7} \\
0.02 \\
5\end{array}$ & - & - & - & - & - & $\begin{array}{c}\underline{5} \\
0.01 \\
8 \\
\end{array}$ \\
\hline $\begin{array}{l}\text { Trachelomonas } \\
\text { volvocina Ehrenb. } \\
\text { var. coronata } \\
\text { Lemmerm. }\end{array}$ & - & - & - & 0.01 & $\begin{array}{c}\frac{12}{0.02} \\
5\end{array}$ & $\begin{array}{c}\frac{7}{7} \\
4\end{array}$ & - & - & $\begin{array}{c}\frac{4}{0.00} \\
8\end{array}$ & $\begin{array}{l}0.00 \\
6\end{array}$ & - & - \\
\hline $\begin{array}{l}\text { Trachelomonas } \\
\text { volvocina Ehrenb. } \\
\text { var. volvocina }\end{array}$ & - & $\begin{array}{c}\frac{3.5}{0.00} \\
7\end{array}$ & $\begin{array}{c}\underline{4} \\
0.00 \\
8\end{array}$ & - & $\frac{24}{0.05}$ & $\begin{array}{c}\frac{28}{0.05} \\
8\end{array}$ & $\begin{array}{l}\frac{63}{0.13} \\
2\end{array}$ & - & $\begin{array}{c}\underline{8} \\
0.01 \\
6\end{array}$ & $\begin{array}{c}\frac{15}{0.03} \\
1\end{array}$ & - & - \\
\hline $\begin{array}{l}\text { Trachelomonas } \\
\text { volvocina var. } \\
\text { punctata Playfair }\end{array}$ & - & - & $\begin{array}{c}\underline{4} \\
0.00 \\
8\end{array}$ & $\begin{array}{c}\frac{25}{0.05} \\
2\end{array}$ & $\begin{array}{c}\underline{6} \\
0.01 \\
2\end{array}$ & $\begin{array}{c}\frac{21}{0.04} \\
4\end{array}$ & - & - & - & $\begin{array}{c}\underline{9} \\
0.01 \\
8\end{array}$ & $\begin{array}{c}\stackrel{4}{6} \\
0.00\end{array}$ & - \\
\hline $\begin{array}{l}\text { Trachelomonas } \\
\text { volvocinopsis } \\
\text { Svirenko }\end{array}$ & - & - & $\begin{array}{l}\frac{4}{0} \\
3\end{array}$ & $\begin{array}{c}\frac{15}{0.01} \\
2\end{array}$ & $\begin{array}{c}\underline{6} \\
0.00 \\
4\end{array}$ & $\begin{array}{c}\underline{14} \\
0.01 \\
1\end{array}$ & - & - & $\begin{array}{l}\underline{8} \\
0.00 \\
6\end{array}$ & - & - & $\begin{array}{c}0.00 \\
4\end{array}$ \\
\hline \multicolumn{13}{|l|}{ Streptophyta } \\
\hline $\begin{array}{l}\text { Cosmarium } \\
\text { bioculatum } \\
\text { Brébisson ex Ralfs }\end{array}$ & - & - & - & - & - & $\begin{array}{c}\frac{7}{7} 2 \\
9\end{array}$ & $\begin{array}{c}\frac{14}{0.05} \\
8 \\
\end{array}$ & $\begin{array}{c}\underline{8} \\
0.03 \\
4\end{array}$ & - & - & - & - \\
\hline $\begin{array}{l}\text { Cosmarium } \\
\text { lapponicum Borge }\end{array}$ & - & - & - & - & - & - & $\begin{array}{c}\frac{21}{0.13} \\
2 \\
\end{array}$ & - & - & - & - & - \\
\hline \multicolumn{13}{|l|}{ Xanthophyta } \\
\hline $\begin{array}{l}\text { Ophiocytium } \\
\text { capitatum Wolle }\end{array}$ & - & - & - & - & - & - & $\begin{array}{c}\frac{7}{700} \\
9\end{array}$ & - & - & - & - & - \\
\hline
\end{tabular}


Appendix 2: The algal indicators in the communities of the Southern Bug River (Khmelnitsky station) with species autecology (Barinova et al., 2006).

\begin{tabular}{|c|c|c|c|c|c|c|c|c|c|}
\hline Species & Hab & $\mathrm{T}$ & Oxy & $\mathrm{D}$ & Sal & $\mathrm{pH}$ & $\mathrm{S}$ & Het & Tro \\
\hline \multicolumn{10}{|l|}{ Bacillariophyta } \\
\hline Achnanthidium minutissima & - & - & - & - & - & - & - & - & - \\
\hline Amphora ovalis & B & temp & st-str & sx & $\mathrm{i}$ & alf & a-b & ate & $\mathrm{e}$ \\
\hline Aulacoseira granulata granulata & - & - & - & - & - & - & - & - & - \\
\hline Cocconeis placentula & P-B & temp & st-str & es & $\mathrm{i}$ & alf & o-b & ate & e \\
\hline Cyclostephanos dubius & - & - & st-str & - & $\mathrm{hl}$ & alb & o-b & ate & $\mathrm{e}$ \\
\hline Cyclostephanos invisitatus & - & - & - & es & - & - & o-b & - & - \\
\hline Cyclotella meneghiniana & P-B & temp & st & sp & $\mathrm{hl}$ & alf & o-a & hne & $\mathrm{e}$ \\
\hline Cymbella lanceolata & $\mathrm{B}$ & - & str & sx & $\mathrm{i}$ & alf & 0 & ats & o-e \\
\hline Diatoma mesodon & $\mathrm{B}$ & cool & st-str & sx & $\mathrm{hb}$ & neu & o-b & ats & $\mathrm{m}$ \\
\hline Encyonema caespitosum & $\mathrm{B}$ & - & - & $\mathrm{sx}$ & - & - & b-a & - & - \\
\hline Encyonema minuta & - & - & - & - & - & - & - & - & - \\
\hline Fragilaria crotonensis & $\mathrm{P}$ & - & St & es & $\mathrm{Hl}$ & alf & $\mathrm{a}-\mathrm{b}$ & ate & $\mathrm{m}$ \\
\hline Gomphonema clavatum & $\mathrm{B}$ & - & str & es & $\mathrm{i}$ & ind & o-b & ats & me \\
\hline Gomphonema minutum & $\mathrm{B}$ & - & - & es & oh & alf & o-b & - & $\mathrm{e}$ \\
\hline Melosira varians & P-B & temp & st-str & es & hl & alf & $a-b$ & hne & $\mathrm{e}$ \\
\hline Navicula cryptotenella & $\mathrm{B}$ & - & - & sx & $\mathrm{i}$ & ind & o-b & - & o-e \\
\hline Navicula tripunctata & $\mathrm{B}$ & - & st-str & es & $\mathrm{i}$ & ind & $\mathrm{b}$ & ate & $\mathrm{e}$ \\
\hline Stephanodiscus hantzschii & $\mathrm{P}$ & temp & st & es & $\mathrm{i}$ & alf & $a-b$ & hne & he \\
\hline Ulnaria acus & $\mathrm{P}$ & - & st-str & es & $\mathrm{i}$ & alb & o-a & - & - \\
\hline Ulnaria ulna & B & temp & st-str & es & $\mathrm{i}$ & alf & b-o & ate & o-e \\
\hline \multicolumn{10}{|l|}{ Chlorophyta } \\
\hline Actinastrum hantzschii hantzschii & P-B & - & st-str & - & $\mathrm{i}$ & - & $\mathrm{b}$ & - & - \\
\hline Actinastrum hantzschii subtile & P-B & - & - & - & $\mathrm{i}$ & - & $\mathrm{b}$ & - & - \\
\hline Acutodesmus obliquus & - & - & - & - & - & - & - & - & - \\
\hline Acutodesmus pectinatus pect. & - & - & - & - & - & - & - & - & - \\
\hline Coelastrum astroideum & $\mathrm{P}$ & - & st-str & - & - & - & $\mathrm{b}$ & - & - \\
\hline Coelastrum microporum & $\mathrm{P}-\mathrm{B}$ & - & st-str & - & $\mathrm{i}$ & ind & $\mathrm{b}$ & - & - \\
\hline Coenococcus polycoccus & - & - & - & - & - & - & - & - & - \\
\hline Crucigenia tetrapedia & P-B & - & st-str & - & $\mathrm{i}$ & ind & o-a & - & - \\
\hline Crucigeniella apiculata & P-B & - & st-str & - & - & - & $\mathrm{b}$ & - & - \\
\hline Desmodesmus armatus & P-B & - & st-str & - & - & - & $\mathrm{o}-\mathrm{a}$ & - & - \\
\hline Desmodesmus bicaudatus & - & - & - & - & - & - & - & - & - \\
\hline Desmodesmus brasiliensis & $\mathrm{P}-\mathrm{B}$ & - & st-str & - & - & - & $\mathrm{b}$ & - & - \\
\hline Desmodesmus communis com. & - & - & - & - & - & - & - & - & - \\
\hline Desmodesmus costato-granulatus & $\mathrm{P}-\mathrm{B}$ & - & st-str & - & - & - & $\mathrm{b}$ & - & - \\
\hline Desmodesmus denticulatus & P-B & - & st-str & - & $\mathrm{i}$ & - & $\mathrm{b}$ & - & - \\
\hline Desmodesmus intermedius acut. & - & - & - & - & - & - & - & - & - \\
\hline Desmodesmus lefevrei & - & - & - & - & - & - & $\mathrm{b}$ & - & - \\
\hline Desmodesmus subspicatus subsp. & P-B & - & st-str & - & - & - & o & - & - \\
\hline Dictyosphaerium granulatum & - & - & - & - & - & - & - & - & - \\
\hline Dictyosphaerium pulchellum & P-B & - & st-str & - & $\mathrm{i}$ & ind & $\mathrm{b}$ & - & - \\
\hline
\end{tabular}


Appendix 2 (continuing): The algal indicators in the communities of the Southern Bug River (Khmelnitsky station) with species autecology (Barinova et al., 2006).

\begin{tabular}{|c|c|c|c|c|c|c|c|c|c|}
\hline Species & Hab & $\mathrm{T}$ & Oxy & $\mathrm{D}$ & Sal & $\mathrm{pH}$ & $\mathrm{S}$ & Het & Tro \\
\hline Enallax acutiformis acutiformis & - & - & - & - & - & - & - & - & - \\
\hline Enallax acutiformis var. costatus & - & - & - & - & - & - & - & - & - \\
\hline Granulocystopsis coronata & - & - & - & - & - & - & $\mathrm{b}$ & - & - \\
\hline Kirchneriella lunaris & P-B & - & st-str & - & $\mathrm{i}$ & - & $\mathrm{b}$ & - & - \\
\hline Koliella longiseta & $\mathrm{P}$ & - & st & - & $\mathrm{i}$ & - & $\mathrm{b}$ & - & - \\
\hline Lagerheimia wratislaviensis & P-B & - & st-str & - & - & - & $\mathrm{b}$ & - & - \\
\hline Micractinium pusillum & P-B & - & st-str & - & - & - & b-a & - & - \\
\hline Monactinus simplex & - & - & - & - & - & - & - & - & - \\
\hline Monactinus simplex echinulatum & - & - & - & - & - & - & - & - & - \\
\hline Monoraphidium arcuatum & P-B & - & st-str & - & - & - & $\mathrm{b}$ & - & - \\
\hline Monoraphidium griffithii & P-B & - & st-str & - & - & - & $\mathrm{b}$ & - & - \\
\hline Monoraphidium minutum & P-B & - & st-str & - & - & - & b-a & - & - \\
\hline Oocystis lacustris & P-B & - & st-str & - & $\mathrm{hl}$ & - & b-o & - & - \\
\hline Pediastrum duplex var. duplex & $\mathrm{P}$ & - & st-str & - & i & ind & o-a & - & - \\
\hline Pediastrum duplex subgranul. & P-B & - & st-str & - & - & - & - & - & - \\
\hline Pseudopediastrum boryanum & & - & - & - & - & - & - & - & - \\
\hline Pseudopediastrum boryanum lon. & - & - & - & - & - & - & - & - & - \\
\hline Raphidocelis sigmoidea & $\mathrm{P}$ & - & st-str & - & - & - & - & - & - \\
\hline Scenedesmus ellipticus & P-B, $S$ & - & st-str & - & - & - & o-b & - & - \\
\hline Scenedesmus obtusus obtusus & - & - & - & - & - & - & - & - & - \\
\hline Tetraedron minimum & P-B & - & st-str & - & $\mathrm{i}$ & - & $\mathrm{b}$ & - & - \\
\hline Tetraedron triangulare & P-B & - & st-str & - & $\mathrm{i}$ & - & $\mathrm{b}$ & - & - \\
\hline Tetrastrum staurogeniaeforme & P-B & - & st-str & - & $\mathrm{i}$ & - & $\mathrm{b}$ & - & - \\
\hline Tetrastrum triangulare & P-B & - & st-str & - & - & - & $\mathrm{b}$ & - & - \\
\hline Treubaria triappendiculata & P-B & - & st-str & - & - & - & - & - & - \\
\hline Westella botryoides & $\mathrm{P}$ & - & st-str & - & - & - & $\mathrm{b}$ & - & - \\
\hline \multicolumn{10}{|l|}{ Chrysophyta } \\
\hline Dinobryon divergens & $\mathrm{P}$ & - & st-str & - & $\mathrm{i}$ & ind & $0-\mathrm{a}$ & - & - \\
\hline Pseudokephyrion cylindricum & - & - & - & - & - & - & b-o & - & - \\
\hline Pseudokephyrion latum & - & - & - & - & - & - & - & - & - \\
\hline Pseudokephyrion schilleri & - & - & - & - & - & - & - & - & - \\
\hline \multicolumn{10}{|l|}{ Cyanoprokaryota } \\
\hline Aphanizomenon elenkinii & B & - & - & - & - & - & b-o & - & - \\
\hline Aphanizomenon flos-aquae & $\mathrm{P}$ & - & - & - & $\mathrm{hl}$ & - & $\mathrm{b}$ & - & - \\
\hline Aphanocapsa planctonica & $\mathrm{P}$ & - & - & - & i & - & - & - & - \\
\hline Dolichospermum flos-aquae & - & - & - & - & - & - & - & - & - \\
\hline Microcystis aeruginosa & $\mathrm{P}$ & - & - & - & $\mathrm{hl}$ & - & o-a & - & - \\
\hline Microcystis firma & $\mathrm{P}$ & - & - & - & - & - & 0 & - & - \\
\hline Oscillatoria amphibia & P-B, S & - & st-str & - & $\mathrm{hl}$ & - & $0-\mathrm{a}$ & - & - \\
\hline Oscillatoria tenuis & P-B, S & - & st-str & - & $\mathrm{hl}$ & - & $\mathrm{b}-\mathrm{a}$ & - & - \\
\hline \multicolumn{10}{|l|}{ Dinophyta } \\
\hline Ceratium hirundinella & $\mathrm{P}$ & - & st-str & - & $\mathrm{i}$ & - & 0 & - & - \\
\hline Gymnodinium paradoxum & - & - & - & - & - & - & - & - & - \\
\hline
\end{tabular}


Appendix 2 (continuing): The algal indicators in the communities of the Southern Bug River (Khmelnitsky station) with species autecology (Barinova et al., 2006).

\begin{tabular}{|l|c|c|c|c|c|c|c|c|c|}
\hline Peridiniopsis polonicum & $\mathrm{P}$ & - & st & - & - & - & - & - & - \\
\hline Peridinium aciculiferum & - & - & - & - & - & - & o-b & - & - \\
\hline \multicolumn{1}{|c|}{ Euglenophyta } & & & & & & & & & \\
\hline Euglena acus & P & eterm & st & - & i & ind & b & - & - \\
\hline Euglena granulata & P & eterm & st-str & - & mh & ind & b-a & - & - \\
\hline Euglena oblonga & P & eterm & st-str & - & Ph & ind & b & - & - \\
\hline Lepocinclis fusiformis & P & eterm & st-str & - & i & ind & b & - & - \\
\hline Phacus acuminatus & P-B & eterm & st-str & - & i & - & b-a & - & - \\
\hline Phacus curvicauda & P-B & - & st & - & i & ind & b & - & - \\
\hline Phacus longicauda longicauda & - & - & - & - & - & - & - & - & - \\
\hline Phacus orbicularis & P-B & - & st-str & - & i & ind & b & - & - \\
\hline Trachelomonas nigra & P & cool & st-str & - & hl & - & b & - & - \\
\hline Trachelomonas volvocina coron. & - & - & - & - & - & - & - & - & - \\
\hline Trachelomonas volvocina volv. & B & eterm & st-str & - & i & ind & b & - & - \\
\hline Trachelomonas volvocina punct. & - & - & - & - & - & - & - & - & - \\
\hline Trachelomonas volvocinopsis & P & - & st-str & - & i & - & b & - & - \\
\hline
\end{tabular}


